Prepared in cooperation with the Illinois Environmental Protection Agency

\title{
Use of Real-Time Sensors to Temporally Characterize Water Quality in Groundwater and Surface Water in Mason County, Illinois, 2017-19
}

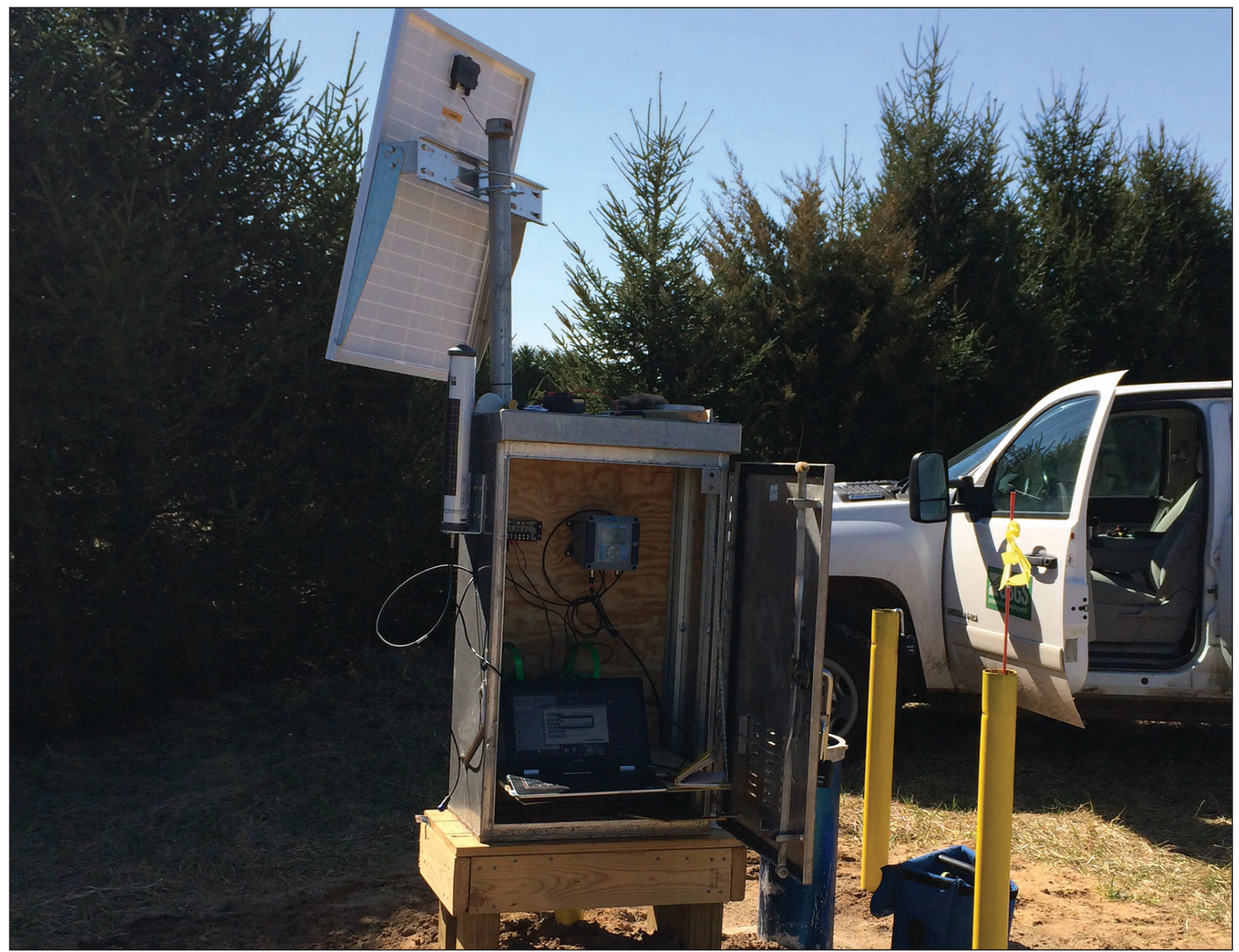

Scientific Investigations Report 2020-5108 
Front Cover: Photograph showing continuous groundwater monitoring well, U.S. Geological Survey station 401913089534501 . Photograph by William S. Morrow, U.S. Geological Survey. 


\section{Use of Real-Time Sensors to Temporally Characterize Water Quality in Groundwater and Surface Water in Mason County, Illinois, 2017-19}

By Lance R. Gruhn and William S. Morrow

Prepared in cooperation with the Illinois Environmental Protection Agency

Scientific Investigations Report 2020-5108 


\title{
U.S. Department of the Interior \\ DAVID BERNHARDT, Secretary
}

\author{
U.S. Geological Survey \\ James F. Reilly II, Director
}

U.S. Geological Survey, Reston, Virginia: 2020

For more information on the USGS - the Federal source for science about the Earth, its natural and living resources, natural hazards, and the environment—visit https://www.usgs.gov or call 1-888-ASK-USGS.

For an overview of USGS information products, including maps, imagery, and publications, visit https://store.usgs.gov/.

Any use of trade, firm, or product names is for descriptive purposes only and does not imply endorsement by the U.S. Government.

Although this information product, for the most part, is in the public domain, it also may contain copyrighted materials as noted in the text. Permission to reproduce copyrighted items must be secured from the copyright owner.

Suggested citation:

Gruhn, L.R., and Morrow, W.S., 2020, Use of real-time sensors to temporally characterize water quality in groundwater and surface water in Mason County, Illinois, 2017-19: U.S. Geological Survey Scientific Investigations Report 2020-5108, 26 p., https://doi.org/10.3133/sir20205108.

ISSN 2328-0328 (online) 


\section{Acknowledgments}

The authors would like to thank Rick Cobb and the Illinois Environmental Protection Agency (IEPA) for their support of past and ongoing studies. Additionally, we would like to thank Lauren Lurkins and associates at the Illinois Farm Bureau for providing a stakeholder review of this report and coordinating meetings that helped gain valuable input from local irrigating farmers and the Illinois Farm Bureau. Special thanks to John Breedlove, the president of the Central Illinois Irrigated Growers Association, and Steve Turner for their insight into irrigated farming operations in the area. We also thank Joe Konczyk (IEPA) and Kevin Rogers (Illinois Department of Agriculture) for their assistance acquiring geospatial information, relevant reports, and other ancillary information relevant to the study. The authors would also like to thank the Imperial Valley Water Authority for furnishing precipitation and estimated irrigation use data. We would like to thank our colleague Jennifer Sharpe of the Central Midwest Water Science Center for her assistance compiling figures and graphs for this report. 



\section{Contents}

Acknowledgments ……...................................................................................................................

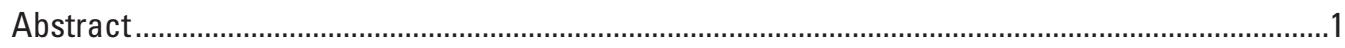

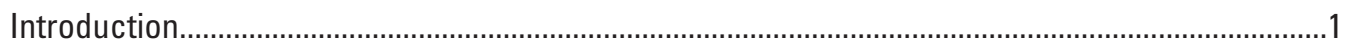

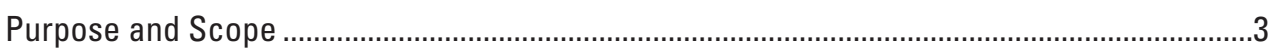

Study Area

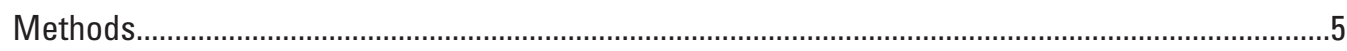

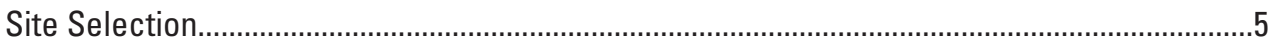

Continuous Groundwater Monitoring Instrumentation ............................................................

Quiver Creek Surface Water and Groundwater Characterization..............................................

Discrete Groundwater Sample Collection and Analysis .....................................................

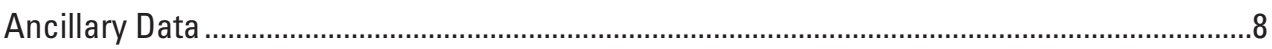

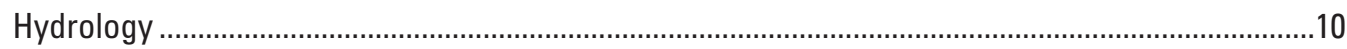

Continuous Groundwater-Quality Data .................................................................................11

Nitrate Concentrations …………………............................................................................

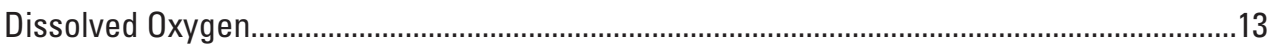

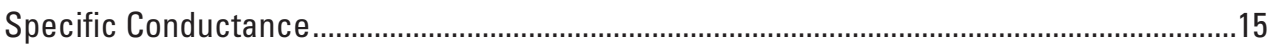

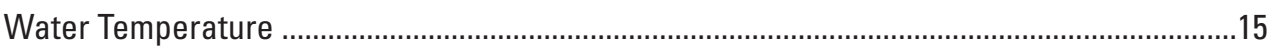

$\mathrm{pH}$

Characterization of Water Quality in Quiver Creek Stream and Floodplain ....................................19

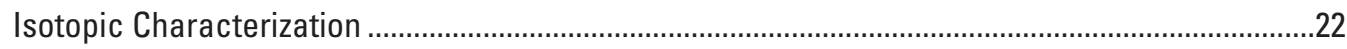

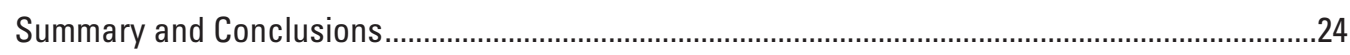

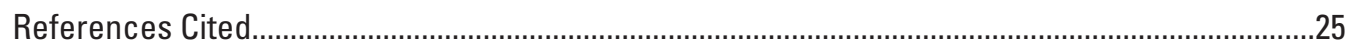

\section{Figures}

1. Map showing nitrate concentrations greater than 10 milligrams per liter in Illinois Department of Agriculture monitoring wells, 2000-14..........................................2

2. Map showing Havana Lowlands region and the extent of the shallow, western part of the Mahomet aquifer in west-central Illinois..........................................................

3. Map showing Havana well location, Quiver Creek measurement location, piezometer locations, and reconnaissance locations, Mason County, Illinois ..................7

4. Graph showing monthly precipitation totals from gage nine of the Imperial Valley Water Authority precipitation network, March 2017-19.

5. Graph showing groundwater elevations plotted for paired piezometers. Quiver Creek surface water with piezometer 1, and the paired shallow and deep piezometers

6. Graph showing nitrate concentration and groundwater elevation in feet above the North American Vertical Datum of 1988, March 8, 2017, to March 31, 2019, U.S. Geological Survey station 401913089534501

7. Graph showing nitrate concentration, dissolved oxygen, and groundwater elevation in feet above the North American Vertical Datum of 1988, March 8, 2017, to March 31, 2019, U.S. Geological Survey station 401913089534501. 
8. Graph showing nitrate concentration, dissolved oxygen, and groundwater elevation in feet above the North American Vertical Datum of 1988, during 2017 peak irrigation period, May 1 to August 31, U.S. Geological Survey station 401913089534501

9. Graph showing nitrate concentration, dissolved oxygen, and groundwater elevation in feet above the North American Vertical Datum of 1988, during 2018 peak irrigation period, May 1 to August 31, U.S. Geological Survey station 401913089534501

10. Graph showing nitrate concentration, specific conductance, and groundwater elevation in feet above the North American Vertical Datum of 1988, March 8, 2017, to March 31, 2019, U.S. Geological Survey station 401913089534501.

11. Graph showing nitrate concentration, specific conductance, and groundwater elevation in feet above the North American Vertical Datum of 1988, during 2017 peak irrigation period, May 1 to August 31, U.S. Geological Survey station 401913089534501

12. Graph showing nitrate concentration, specific conductance, and groundwater elevation in feet above the North American Vertical Datum of 1988, during 2018 peak irrigation period, May 1 to August 31, U.S. Geological Survey station 401913089534501

13. Graph showing nitrate concentration, temperature, and groundwater elevation in feet above the North American Vertical Datum of 1988, March 8, 2017, to March 31, 2019, U.S. Geological Survey station 401913089534501

14. Graph showing nitrate, $\mathrm{pH}$, and groundwater elevation in feet above the North American Vertical Datum of 1988, March 8, 2017, to March 31, 2019, U.S. Geological Survey station 401913089534501

15. Graph showing continuous groundwater levels and groundwater nitrate concentrations at U.S. Geological Survey station 401913089534501, plotted with instantaneous measurements of nitrate in Quiver Creek surface water

16. Graph showing nitrate concentrations in Quiver Creek and the shallow piezometers in the floodplain April 4, 2018, to December 19, 2018

17. Graph showing stable isotopic composition of water from Havana well and Quiver Creek piezometers plotted on the Global Meteoric Water Line, Mason County, Illinois

18. Graph showing nitrate isotopes for Havana well and Quiver Creek piezometers,

Mason County, Illinois

\section{Tables}

1. Information on data collection sites, Mason County, Illinois 2017-19.

2. Imperial Valley Water Authority's estimated irrigation usage in gallons for 2017 and 2018.

3. Summary of discrete water-quality results from the U.S. Geological Survey National Water Quality Laboratory analysis of nutrients.

4. Range of instantaneous measurements of water quality and water-level elevations, April 11, 2017, to February 5, 2019, Mason County, Illinois

5. Summary of results of stable isotopes of water and nitrate isotopes in groundwater, Mason County, Illinois. 


\section{Conversion Factors}

U.S. customary units to International System of Units

\begin{tabular}{|c|c|c|}
\hline Multiply & By & To obtain \\
\hline \multicolumn{3}{|c|}{ Length } \\
\hline inch (in.) & 2.54 & centimeter $(\mathrm{cm})$ \\
\hline inch (in.) & 25.4 & millimeter (mm) \\
\hline foot $(\mathrm{ft})$ & 0.3048 & meter $(\mathrm{m})$ \\
\hline mile (mi) & 1.609 & kilometer $(\mathrm{km})$ \\
\hline
\end{tabular}

International System of Units to U.S. customary units

\begin{tabular}{lll}
\hline & \multicolumn{1}{c}{ Multiply } & \multicolumn{1}{c}{ Bo obtain } \\
\hline & Length & \\
\hline centimeter $(\mathrm{cm})$ & 0.3937 & inch (in.) \\
millimeter $(\mathrm{mm})$ & 0.03937 & inch (in.) \\
meter $(\mathrm{m})$ & 3.281 & foot (ft) \\
kilometer $(\mathrm{km})$ & 0.6214 & mile (mi) \\
kilometer $(\mathrm{km})$ & 0.5400 & mile, nautical (nmi) \\
meter $(\mathrm{m})$ & 1.094 & yard (yd) \\
\hline
\end{tabular}

Temperature in degrees Celsius $\left({ }^{\circ} \mathrm{C}\right)$ may be converted to degrees Fahrenheit $\left({ }^{\circ} \mathrm{F}\right)$ as follows:

$$
{ }^{\circ} \mathrm{F}=\left(1.8 \times{ }^{\circ} \mathrm{C}\right)+32 .
$$

Temperature in degrees Fahrenheit $\left({ }^{\circ} \mathrm{F}\right)$ may be converted to degrees Celsius $\left({ }^{\circ} \mathrm{C}\right)$ as follows:

$$
{ }^{\circ} \mathrm{C}=\left({ }^{\circ} \mathrm{F}-32\right) / 1.8 \text {. }
$$

\section{Datum}

Vertical coordinate information is referenced to the North American Vertical Datum of 1988 (NAVD 88).

Horizontal coordinate information is referenced to the North American Datum of 1983 (NAD 83)

Elevation, as used in this report, refers to distance above the vertical datum. 


\section{Supplemental Information}

Concentrations of chemical constituents in water are given in milligrams per liter (mg/L).

Specific conductance is given in microsiemens per centimeter at 25 degrees Celsius $(\mu \mathrm{S} / \mathrm{cm}$ at $\left.25^{\circ} \mathrm{C}\right)$.

Results for measurements of stable isotopes of an element (with symbol E) in water, solids, and dissolved constituents commonly are expressed as the relative difference in the ratio of the number of the less abundant isotope (iE) to the number of the more abundant isotope of a sample with respect to a measurement standard.

\section{Abbreviations}

$<\quad$ less than

HL Havana Lowlands

IEPA Illinois Environmental Protection Agency

IVWA Imperial Valley Water Authority

USGS U.S. Geological Survey 


\title{
Use of Real-Time Sensors to Temporally Characterize Water Quality in Groundwater and Surface Water in Mason County, Illinois, 2017-19
}

\author{
By Lance R. Gruhn and William S. Morrow
}

\section{Abstract}

The persistence of high nitrate concentrations in shallow groundwater has been well documented in the shallow glacial aquifer of Mason County, Illinois. Nitrates in groundwater can be a concern when concentrations exceed 10 milligrams per liter in drinking water. Additionally, nitrate in groundwater can contribute to surface water nitrogen loads that can cause increased algal growth. Algal growth increases oxygen consumption causing anoxic conditions as observed in the Gulf of Mexico Hypoxic Zone.

From March 8, 2017, to March 31, 2019, groundwater level, continuous nitrate, dissolved oxygen, specific conductance, water temperature, and $\mathrm{pH}$ data were collected in a monitoring well to temporally assess changes in water quality using high frequency data. During this same period, instantaneous field measurements of water quality and groundwater levels were made in surface water and groundwater in and near Quiver Creek in the presumed groundwater flow path about 0.6 mile from the continuous monitoring well. Groundwater nitrate concentrations continuously measured in the aquifer during this time ranged from 14.7 to 23.2 milligrams per liter, whereas instantaneously measured nitrate concentrations in Quiver Creek ranged from 0.9 to 6.4 milligrams per liter. Nitrate concentrations measured by piezometer varied laterally and vertically in the Quiver Creek floodplain and beneath the stream. Irrigation and fertigation for agriculture is widely practiced in Mason County. This may seasonally affect the groundwater flow and movement as well as the persistence of nitrate in this area. Continuously and instantaneously measured nitrate concentrations and groundwater levels indicate that during the irrigation season, discharge to Quiver Creek from the shallow groundwater system may be limited. During and following periods when estimated irrigation use is highest, the low-nitrate deeper groundwater may be the dominant contributor to the Quiver Creek surface water, whereas during recharge events and when the system is not under the stress of irrigation, there is more contribution from the local and higher-nitrate shallow groundwater.

\section{Introduction}

Illinois has some of the most productive farmland in the United States. The use of fertilizers has increased to improve crop production and has resulted in an increase in the concentrations of nitrogen in many streams and aquifers (Dubrovsky and others, 2010). From 2000 to 2014 the Illinois Department of Agriculture biennially sampled their network of monitoring wells for concentrations of nitrate plus nitrite as nitrogen (N; hereafter referred to as "nitrate"), for a total of seven samples. These wells are located throughout Illinois adjacent to crop production and where the aquifer materials are within 50 feet (ft) of the land surface. Through this sampling effort, the Illinois Department of Agriculture identified areas in the State where nitrate concentrations are consistently above the State of Illinois class I potable resource groundwater quality standard of 10 milligrams per liter (mg/L, fig. 1) (K. Rogers, Illinois Department of Agriculture, written commun., 2019; Illinois Pollution Control Board, 2019a). The national primary drinking water regulations established by the U.S. Environmental Protection Agency also set a maximum contaminant level of $10 \mathrm{mg} / \mathrm{L}$ for nitrate concentrations in drinking water (U.S. Environmental Protection Agency, 2019). Illinois has codified this maximum contaminant level in 35.Ill. Adm.Code 611.301 (Illinois Pollution Control Board, 2019b). Nutrients in surface water also contribute to nutrient concentrations in the Gulf of Mexico, resulting in increased algal growth, which leads to increased oxygen consumption and creates anoxic conditions, referred to as the Gulf of Mexico Hypoxic Zone (U.S. Environmental Protection Agency, 2020).

A study of nitrate in the Mississippi River and several smaller river basins concluded that some of the highest concentrations of nitrate were observed during low-flow conditions, indicating that a large nutrient load may be transported to the river through groundwater or point source contribution (Murphy and others, 2013). During low-flow conditions, groundwater is presumed to be a large contributor to the total volume of surface water. The area in and around Mason County, Illinois, has several wells that have had numerous 


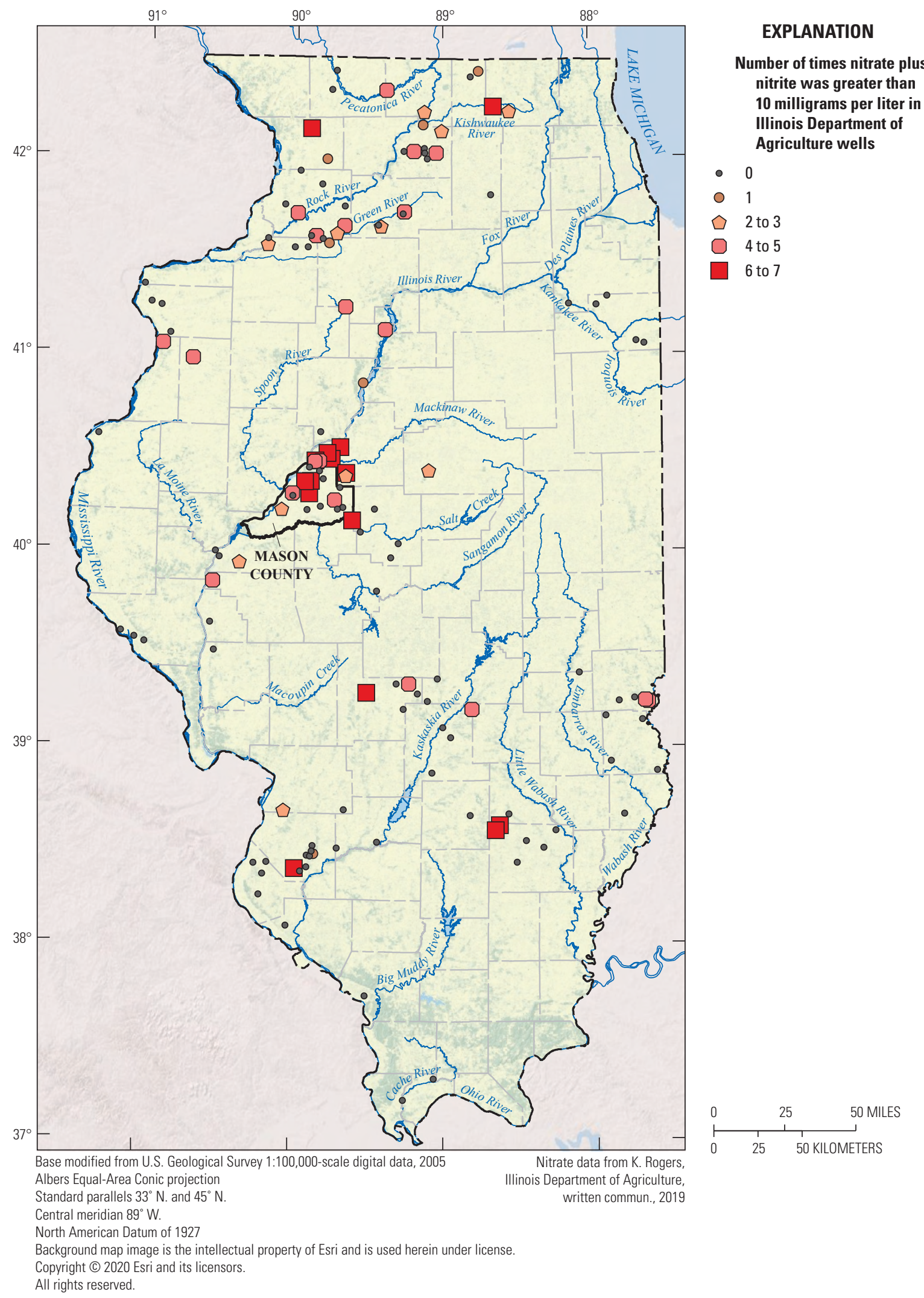

Figure 1. Nitrate concentrations greater than 10 milligrams per liter in Illinois Department of Agriculture monitoring wells, 2000-14 (K. Rogers, Illinois Department of Agriculture, written commun., 2019). 
detections of nitrate concentrations in groundwater greater than $10 \mathrm{mg} / \mathrm{L}$. These wells are grouped together in a shallow glacial aquifer, in an area known as the Havana Lowland (HL) region. Agriculture is the dominant land use in this area, and the HL region is one of the most heavily irrigated agricultural areas in Illinois (Bridges and Wilson, 2014). In November 2014, the Illinois Environmental Protection Agency and the Illinois Department of Agriculture announced the Illinois Nutrient Loss Reduction Strategy, which is an effort to reduce nutrient loads in surface water within the State of Illinois, the Mississippi River Basin, and the Gulf of Mexico (Illinois Department of Agriculture, 2019). Based on findings in Murphy and others (2013), a detailed assessment of nitrate concentrations in groundwater is crucial to understanding the potential effects groundwater may have on nitrate concentrations in surface water.

The U.S. Geological Survey (USGS), in cooperation with the Illinois Environmental Protection Agency (IEPA), completed a study using real-time sensors in Mason County, Illinois, to better understand the fate and transport of nitrate in an area with rapid drainage and intensive irrigation and fertilizer application. More specifically, how nitrate concentrations in groundwater may potentially affect nitrate concentrations in surface water in this type of setting, and the potential relations between nitrate and other water-quality properties and physical and atmospheric data. The results from this study can help inform the Illinois Nutrient Loss Reduction Strategy and other nutrient reduction initiatives on the fluctuations of nitrate concentrations in groundwater and its potential loading to surface water in an area with substantial groundwater discharge.

\section{Purpose and Scope}

The purpose of this report is to describe the findings from continuous data collection using real-time sensors (one reading every 15 minutes) in a groundwater well in a shallow glacial aquifer system in Mason County, Ill., and from instantaneous data (readings collected while onsite) collected in a nearby stream, Quiver Creek, and in the groundwater within the Quiver Creek floodplain, particularly to describe the fate and transport of nitrate as it moves through the shallow aquifer system, the floodplain, and potentially to surface water. Continuous data were analyzed with instantaneous data and discrete water-quality data collected by the USGS, and estimated irrigation use and precipitation data from the Imperial Valley Water Authority (IVWA).

\section{Study Area}

The HL region is in Mason County and the southwestern part of Tazewell County in west-central Illinois. The HL region is bounded to the northwest by the Illinois River, to the south by the Sangamon River and Salt Creek, and to the east by glaciated uplands (fig. 2; Walker and others, 1965; Sanderson and Buck, 1995). Three main physiographic areas within the HL region were identified by Walker and others (1965): (1) the floodplains of the streams and rivers, (2) wide sand-ridged terraces east of the Illinois River, and (3) the loess-covered Illinoian drift upland in southeastern Mason County. The principle surface-water features in the region include the Illinois River, Mackinaw River, Sangamon River, Salt Creek, Crane Creek, and Quiver Creek, which is also known as the Mason-Tazewell Drainage Ditch (fig. 2; Walker and others, 1965; Sanderson and Buck, 1995). The flow of Quiver Creek is primarily, if not entirely, composed of groundwater discharge from the portion of the Mahomet aquifer (Layne Hydro, 2012) that is made up of sands and gravels deposited in the Mahomet bedrock valley (Hackley and others, 2010).

The surficial geology of the HL region consists primarily of unconsolidated sand and gravel deposits of Pleistocene age overlying Pennsylvanian bedrock valleys (Kelly, 1997). These sand and gravel deposits that make up the Mahomet aquifer in the HL region consist of the Sankoty Sand Member of the Banner Formation overlain by glacial outwash deposits of Wisconsinan age (Kelly and Ray, 1999). With respect to nitrate and dissolved oxygen, there is a shallow portion (hereafter referred to as "shallow") of this unconsolidated aquifer that is geochemically different than the deeper part of the aquifer (hereafter referred to as "deeper"). The aquifer often exceeds $100 \mathrm{ft}$ in thickness and in some areas exceeds more than $200 \mathrm{ft}$ (Walker and others, 1965). Sediments are hydraulically conductive and capable of allowing rapid drainage and infiltration. Extensive information about the geology of this area is discussed in Walker and others (1965).

Climate in the HL region shows typical midcontinental characteristics with cold winters and humid, warm summers. Most precipitation occurs during the warmer months with variability (sometimes large) in temperature and precipitation from year to year (Sanderson and Buck, 1995).

Agriculture is the dominant land use in the HL region (Bridges and Wilson, 2014). Despite typically ample precipitation and owing to the low water-retention properties of the sandy soil, farmers use agricultural methods that include extensive center pivot irrigation and the application of watersoluble fertilizer, also known as fertigation. Roadcap and others (2002) discuss the timing and type of fertilization, with anhydrous ammonium being physically added to soils in March, April, and June; and liquid fertilizer being added in May, June, and the beginning of July through fertigation. Type and amount of fertilizer application can be spatially and temporally variable dependent on precipitation, crop rotations, seasonality, and water table fluctuations. The IVWA, which comprises all of Mason County and four townships in Tazewell County, compiles data on estimated irrigation usage and precipitation within the HL region (Imperial Valley Water Authority, 2019). Estimated irrigation usage varies from year to year driven mostly by weather conditions, but also by crop types and number of acres planted. According to Bowman and others (1991), irrigation wells in this area normally range from 75 to $150 \mathrm{ft}$ deep and regularly produce 1,000 gallons per 


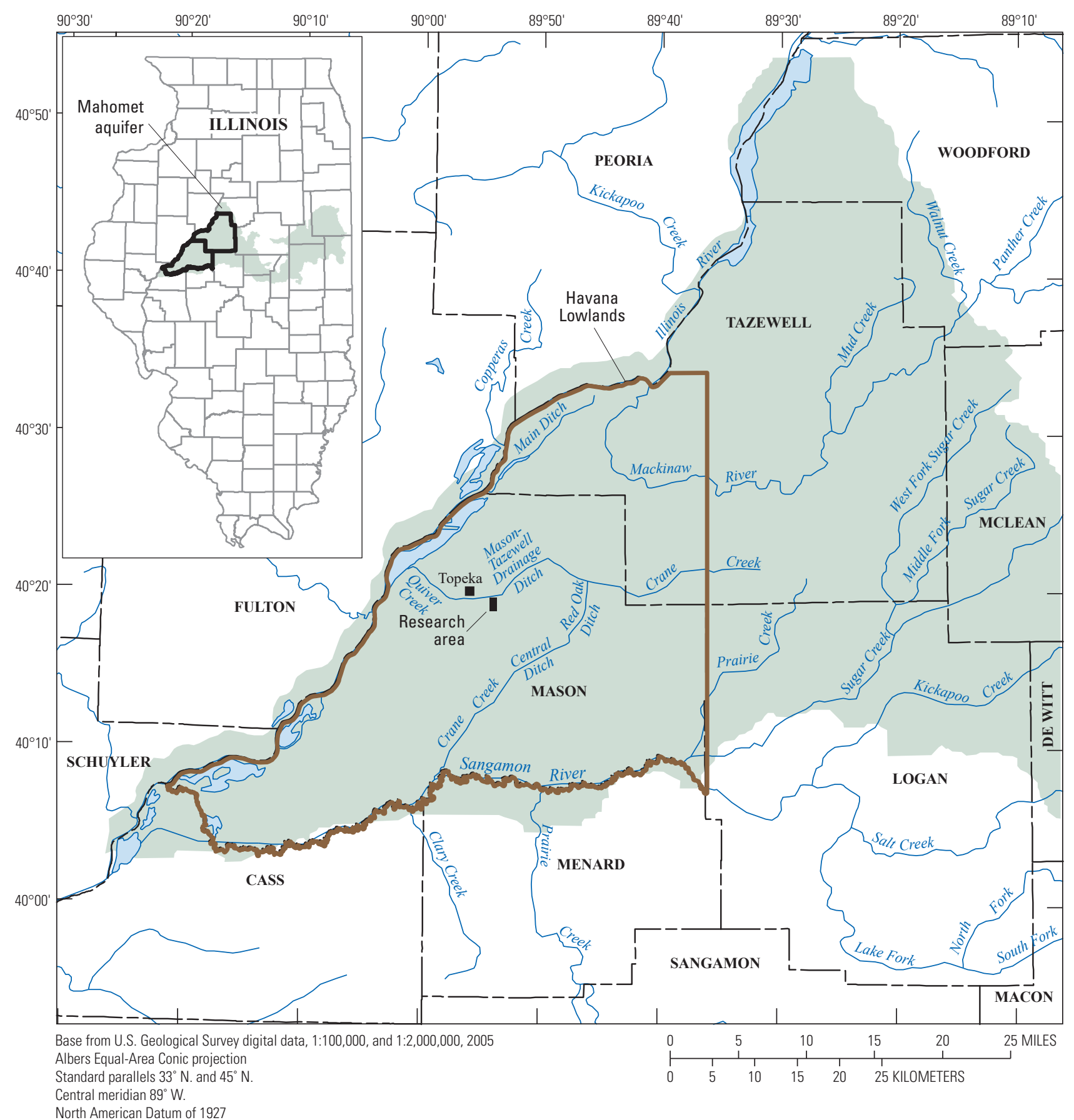

Figure 2. Havana Lowlands region and the extent of the shallow, western part of the Mahomet aquifer in west-central Illinois. 
minute or greater. Crop production land in this area is dominated by corn and soybeans; other notable crops grown in the area include popcorn, pumpkins, beans, and smaller amounts of other specialty fruits and vegetables (U.S. Department of Agriculture, 2017).

\section{Methods}

Beginning March 8, 2017, the USGS in cooperation with the IEPA has been continuously monitoring water quality and water levels (one reading every 15 minutes) in a groundwater monitoring well (USGS station 401913089534501 ; hereafter referred to as the "Havana well") in the HL region. Prior to the project commencing, a Quality Assurance Project Plan was developed with IEPA to help guide project tasks and ensure quality control and assurance of collected data (R. Cobb, Illinois Environmental Protection Agency, written commun., 2020). Parameters continuously monitored include groundwater levels, nitrate, $\mathrm{pH}$, specific conductance, dissolved oxygen, and water temperature. To better understand water quality and hydrology, it is beneficial to collect spatially and temporally dense data and assess those data with physical and atmospheric data. To assess the fate and transport of nitrate in shallow groundwater, continuous water-quality and groundwater-level data were collected in the Havana well on the Mason State Tree Nursery. About 0.6 mile northwest of the Havana well, a surface-water site was established in Quiver Creek, and a series of piezometers was established in the floodplain. Instantaneous field measurements of the same parameters being continuously measured at the monitoring well were made in Quiver Creek and the associated piezometers (table 1; Gruhn and Nalley, 2020). Parameters instantaneously measured include Quiver Creek water levels, groundwater levels, nitrate, $\mathrm{pH}$, specific conductance, dissolved oxygen, and water temperature. Data collected at sites listed in table 1 can be accessed through the USGS National Water Information System database using the USGS site number (U.S. Geological Survey, 2020).

These data were analyzed with local precipitation data and estimated irrigation usage data provided by the IVWA, which consists of all of Mason County, Ill., and four townships in Tazewell County, Ill. (Imperial Valley Water Authority, 2019).

\section{Site Selection}

The Mason State Tree Nursery location was chosen for the continuous monitoring well because of its accessibility and location within the HL region, proximity to irrigating agricultural operations, and accessible land near Quiver Creek. Prior to determining the location of the Havana well, preliminary assessment of the groundwater nitrate concentrations was conducted in four test holes at the nursery location using a Geoprobe. Geoprobe test holes were chosen based on presumed groundwater flow to Quiver Creek and proximity to irrigating agricultural operations. The Havana well site was chosen near the test hole with the highest nitrate concentration in the northeast quadrant of the Mason State Tree Nursery (fig. 3).

The Havana well was installed for the purpose of continuously monitoring groundwater quality and levels. The well was installed within $150 \mathrm{ft}$ of irrigation practices and about 0.6 mile southeast from the Quiver Creek and the piezometer sites (fig. 3, table 1). The well was constructed on January 11, 2017, and the boring for the well was drilled using a 10-inch (in.) diameter hollow stem auger to accommodate a 4-in. well, which was required to deploy instrumentation down-hole. The well was constructed using polyvinyl chloride materials and was drilled to a depth of $32 \mathrm{ft}$ below land surface, and a slotted screen was installed from 22 to $32 \mathrm{ft}$ below land surface. The well was screened at this depth based on the findings of Kelly (1997), where high nitrate concentrations were measured in groundwater at depths between 20 and $33 \mathrm{ft}$.

A surface-water measurement site was established (USGS station 05568704) in Quiver Creek, also known as the MasonTazewell Drainage Ditch, for collection of instantaneous field measurements of water quality and water levels in the stream. To assess groundwater quality and hydrology beneath Quiver Creek and in the floodplain, a series of piezometers were installed, with shallow piezometers being installed on April 4, 2018, and the deeper piezometers being installed on May 21,2018 . The shallow piezometers were installed by hand and the screened interval for the piezometers on land ranged from 6 to $10 \mathrm{ft}$ below land surface, whereas the piezometer below the streambed was about $3 \mathrm{ft}$ below the bed. The deeper piezometers were installed with a truck-mounted Geoprobe and screened intervals were about 17-19 ft. During visits to the study area, the piezometers were pumped and median field parameters determined using a nitrate meter and multiparameter sonde.

\section{Continuous Groundwater Monitoring Instrumentation}

Water levels and select water-quality properties were collected from March 8, 2017, to March 31, 2019. Nitrate data were collected with a Hach nitrate sensor with 2-millimeter $(\mathrm{mm})$ path length. Other continuous data were collected using an In-Situ Aquatroll 600 multiparameter sonde equipped with a 30-pound per square inch-pressure transducer, luminescent dissolved oxygen probe, $\mathrm{pH}$ probe, specific conductance probe, and water temperature thermistor. Both instruments were suspended within the 10 -ft screened interval of the well casing, with the multiparameter sonde hanging below the nitrate sensor. Data were recorded every 15 minutes and transmitted every 6 hours through a cellular modem delivery using an In-Situ Tube 300S telemetry system and processed to the USGS National Water Information System database. 
Table 1. Information on data collection sites, Mason County, Illinois 2017-19.

[USGS, U.S. Geological Survey; NAVD 88, North American Vertical Datum of 1988; NA, not applicable]

\begin{tabular}{|c|c|c|c|c|c|c|c|c|}
\hline USGS site number & Station name & Field identifier & Latitude & Longitude & $\begin{array}{c}\text { Year } \\
\text { established }\end{array}$ & $\begin{array}{l}\text { Land surface } \\
\text { elevation, in } \\
\text { feet above } \\
\text { NAVD } 88\end{array}$ & $\begin{array}{l}\text { Well depth, } \\
\text { in feet } \\
\text { below land } \\
\text { surface }\end{array}$ & $\begin{array}{c}\text { Screen interval, } \\
\text { in feet below } \\
\text { land surface }\end{array}$ \\
\hline 401913089534501 & $\begin{array}{l}\text { 22N7W-28.5a } \\
\text { (Illinois Tree Nursery) }\end{array}$ & Havana Well & $40^{\circ} 19^{\prime} 13.44^{\prime \prime}$ & $89^{\circ} 53^{\prime} 44.54^{\prime \prime}$ & 2017 & 489.87 & 32.10 & $22.10-32.10$ \\
\hline 401935089542001 & 22N07W-29.1h1 (PZ-1) & PZ-1 & $40^{\circ} 19^{\prime} 34.65^{\prime \prime}$ & $89^{\circ} 54^{\prime} 19.85^{\prime \prime}$ & 2018 & 459.74 & $* 6.54$ & $* * 5.04-6.54$ \\
\hline 401934089542001 & 22N07W-29.1h2 (PZ-2) & PZ-2 & $40^{\circ} 19^{\prime} 34.51^{\prime \prime}$ & $89^{\circ} 54^{\prime} 19.86^{\prime \prime}$ & 2018 & 464.88 & 8.74 & $7.24-8.74$ \\
\hline 401934089542002 & $22 \mathrm{~N} 07 \mathrm{~W}-29.1 \mathrm{~h} 5(\mathrm{PZ}-2 \mathrm{~B})$ & $\mathrm{PZ}-2 \mathrm{~B}$ & $40^{\circ} 19^{\prime} 34.51^{\prime \prime}$ & $89^{\circ} 54^{\prime} 19.86^{\prime \prime}$ & 2018 & 464.80 & 18.80 & $17.30-18.80$ \\
\hline 401933089542001 & 22N07W-29.1h3 (PZ-3) & PZ-3 & $40^{\circ} 19^{\prime} 33.41^{\prime \prime}$ & $89^{\circ} 54^{\prime} 19.98^{\prime \prime}$ & 2018 & 465.44 & 6.84 & $5.34-6.84$ \\
\hline 401933089542002 & 22N07W-29.1h6 (PZ-3B) & PZ-3B & $40^{\circ} 19^{\prime} 33.41^{\prime \prime}$ & $89^{\circ} 54^{\prime} 19.98^{\prime \prime}$ & 2018 & 466.31 & 18.80 & $17.30-18.80$ \\
\hline 401931089542001 & 22N07W-29.1h4 (PZ-4) & $\mathrm{PZ}-4$ & $40^{\circ} 19^{\prime} 30.76^{\prime \prime}$ & $89^{\circ} 54^{\prime} 20.19^{\prime \prime}$ & 2018 & 467.92 & 9.81 & $8.31-9.81$ \\
\hline 401931089542002 & 22N07W-29.1h7 (PZ-4B) & $\mathrm{PZ}-4 \mathrm{~B}$ & $40^{\circ} 19^{\prime} 30.76^{\prime \prime}$ & $89^{\circ} 54^{\prime} 20.19^{\prime \prime}$ & 2018 & 467.96 & 18.80 & $17.30-18.80$ \\
\hline 05568704 & $\begin{array}{l}\text { Mason Tazewell Drainage } \\
\text { Ditch near Topeka, Illinois }\end{array}$ & Quiver Creek & $40^{\circ} 19^{\prime} 35^{\prime \prime}$ & $89^{\circ} 54^{\prime} 20^{\prime \prime}$ & 2017 & 459.74 & NA & NA \\
\hline
\end{tabular}

*Measured from top of casing.

**Screened interval, in feet below top of casing. 


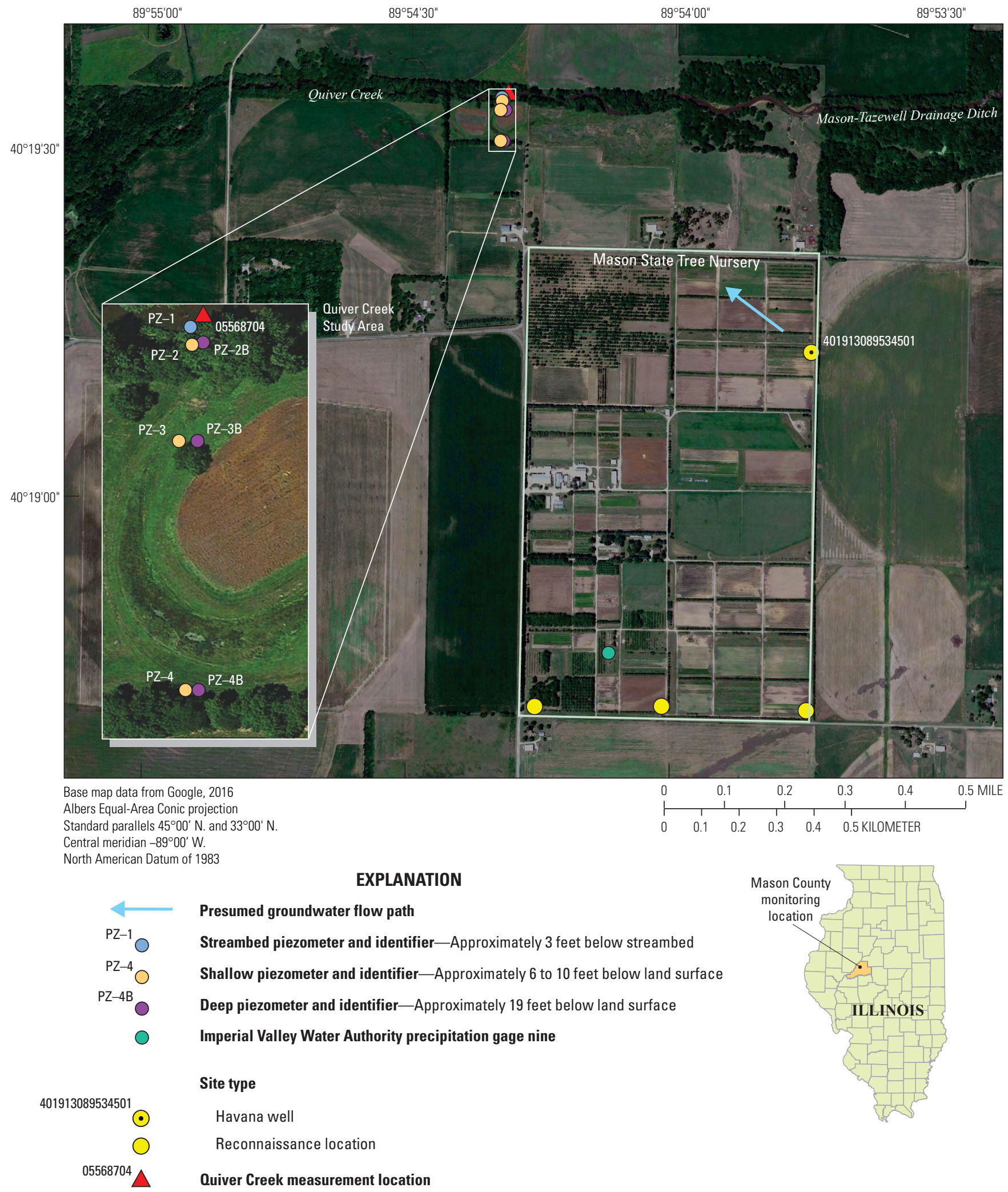

Figure 3. Study area showing Havana well location, Quiver Creek measurement location, piezometer locations, and reconnaissance locations, Mason County, Illinois. 
During visits to the well, which were typically made every 4 to 6 weeks or as needed, the nitrate sensor and multiparameter sonde were checked for calibration drift and biological and physical fouling (the formation of unwanted material on a surface to the detriment of function). Fouling checks were conducted against calibration standards because the monitoring environment is disturbed once the sensors are removed from the well, and it takes time to return to equilibrium with the aquifer, making traditional pre- and postfouling checks prohibitive (Gruhn and Nalley, 2020).

\section{Quiver Creek Surface Water and Groundwater Characterization}

Beginning in April 2017, a nitrate sensor was used to make instantaneous field measurements of nitrate concentration in Quiver Creek during visits to the continuous monitoring well. After a year of collecting instantaneous nitrate data, it was necessary to expand the data collection to include all the parameters being continuously monitored at the well. Beginning in April 2018, water-level measurements were made and a Eureka Manta35 multiparameter sonde was used to measure specific conductance, $\mathrm{pH}$, dissolved oxygen, and temperature in the Quiver Creek surface water.

To characterize water quality and hydrology in the Quiver Creek floodplain and below the streambed of Quiver Creek, a series of piezometers were installed in spring 2018. One piezometer is located beneath the streambed and paired with the surface-water measuring location (Quiver Creek and PZ-1), and the other piezometer locations have paired deep and shallow piezometers. One pair is in the bank of Quiver Creek (PZ-2 and PZ-2B), one pair is about $100 \mathrm{ft}$ landward from Quiver Creek (PZ-3 and PZ-3B), and the final pair is at the edge of the floodplain near the toe of the upland slope about $400 \mathrm{ft}$ landward from Quiver Creek (PZ-4 and PZ-4B) (fig. 3). Beginning in spring 2018, real-time sensors were used to collect instantaneous field measurements of the same water-quality properties monitored at the well in all the piezometers. During visits to the continuous monitoring well, the piezometers were visited and pumped, and measurements made every 2 minutes to determine a stable median value for each parameter.

\section{Discrete Groundwater Sample Collection and Analysis}

To verify the accuracy of the nitrate measurements within the aquifer, four discrete water-quality samples were collected from the Havana well for laboratory analysis after three well volumes were purged and instantaneously measured water quality properties in the well stabilized as specified by the USGS National Field Manual (U.S. Geological Survey, variously dated). The well was sampled three times for nutrients, nitrogen isotopes, and stable isotopes of water - one prior to (April 11, 2017), during (June 13, 2017), and after (October 3 , 2017) intensive agricultural practices. An additional sample only for nitrate analysis was collected to verify accuracy of the sensor on April 3, 2018, following the largest observed peak of nitrate concentration. All samples were processed in the field and filtered with a 0.45 -micron filter, prior to being sent for laboratory analysis. In addition to samples collected at the monitoring well, discrete isotope samples of nitrate and water were also collected from some of the piezometers near Quiver Creek on April 4 and July 18, 2018.

Filtered nutrient samples were analyzed by the USGS National Water Quality Laboratory in Denver, Colorado, using methods described by Fishman (1993) and Patton and Kryskalla $(2003,2011)$. Analytes included total nitrogen, ammonia, nitrite, ortho-phosphate, and nitrate plus nitrite. Stable isotopes of nitrogen (nitrogen 15/14 and oxygen 18/16) and stable isotopes of water (hydrogen-2/1 and oxygen-18/16) were analyzed at the USGS Reston Stable Isotope Laboratory using methods described by Révész and Coplen (2008a), Révész and Coplen (2008b), and Coplen and others (2012). Nitrogen isotope samples had a secondary filtration conducted at the USGS Reston Stable Isotope Laboratory. The results of laboratory analyses for nutrients, nitrogen isotopes, and stable isotopes are available from the USGS National Water Information System database (U.S. Geological Survey, 2020).

\section{Ancillary Data}

Continuous, instantaneous, and discrete data were analyzed with local estimated irrigation usage data and local precipitation data provided by the IVWA (Imperial Valley Water Authority, 2019). The IVWA estimated monthly irrigation usage data is reported in billion gallons with a lag of 1 month due to billing cycles, because energy consumption is used to estimate the amount of irrigation usage (J. Smith, Imperial Valley Water Authority, written commun, 2019). Irrigation season as used in this report is April through September based on the range of months during which estimated irrigation data are compiled by the IVWA (table 2).

The IVWA precipitation network is a spatially distributed and long-term network of rain gages in the HL region. Gage nine in this network is located in the Mason State Tree Nursery. Monthly precipitation reports, including daily rainfall amounts, were acquired for March 2017-19. Monthly totals for gage nine are summarized in figure 4. 
Table 2. Imperial Valley Water Authority's estimated irrigation usage in gallons for 2017 and 2018.

\begin{tabular}{|c|c|c|c|c|c|c|c|}
\hline $\begin{array}{c}\text { Irrigation } \\
\text { season }\end{array}$ & May & June & July & August & September & October & Total \\
\hline *2017 & $15,830,650$ & $1,660,423,448$ & $22,028,339,635$ & $17,329,618,773$ & $14,249,738,293$ & $6,215,554,796$ & $61,499,505,594$ \\
\hline *2018 & $6,538,132,585$ & $15,993,401,247$ & $19,325,900,654$ & $8,748,607,290$ & $1,628,977,028$ & $233,887,871$ & $52,468,906,673$ \\
\hline
\end{tabular}

*Monthly values as reported lag by 1 month due to billing cycle. 


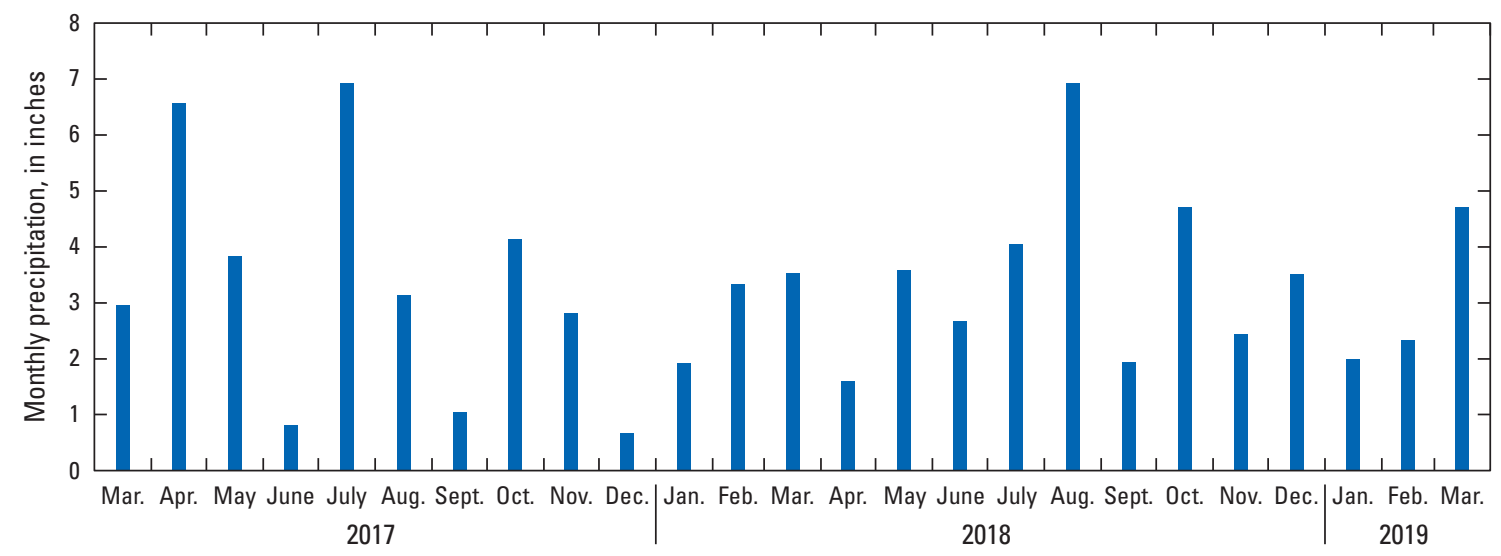

Figure 4. Monthly precipitation totals from gage nine of the Imperial Valley Water Authority precipitation network, March 2017-19 (Imperial Valley Water Authority, 2019).

\section{Hydrology}

Potentiometric surface maps prepared for the HL region indicate groundwater flow is generally in the northwest direction (Walker and others, 1965; Sanderson and Buck, 1995; Kelly and Ray, 1999). Water-level and water-quality data collected for this study indicate that the rate of groundwater flow in the shallow aquifer may be limited in that direction during the irrigation season. Groundwater levels collected at the Havana well during the period of monitoring used for this report ranged in elevation from 474.41 to $470.92 \mathrm{ft}$, or between 15 and $19 \mathrm{ft}$ below land surface, on March 11, 2019, and August 15, 2018, respectively. Water levels consistently decline through most of the irrigation season and rise during late winter/early spring when there is minimal irrigation and little to no plant uptake. In 2017 water levels were stable most of the fall and winter; however, in 2018 water levels began rising in August when there was above average rainfall, resulting in much less irrigation demands. Unlike 2017, when water levels stabilized going into fall and winter, water levels were consistently rising during fall and winter in 2018. Owing to the rapid infiltration rates, the water table responds quickly to precipitation and snowmelt events. In general, during spring, groundwater levels increase until evapotranspiration and irrigation withdrawals begin causing decreases in groundwater levels.

Water-level elevations were temporally and spatially variable across the floodplain and in Quiver Creek (fig. 5). Each water-level measurement made in the piezometer screened below Quiver Creek (PZ-1) was higher than the water level in the stream, indicating predominantly groundwater inflow, or gaining conditions, into Quiver Creek. The one exception was when the water level in Quiver Creek was higher than the water level in PZ-1, which was observed following almost an inch of overnight rainfall in late October 2018. Also, waterlevel measurements made in the nested piezometers (PZ-2/ PZ-2B and PZ-4/PZ-4B) indicated upwelling of groundwater. Quiver Creek and PZ-1, and PZ-2 and PZ-2B, often displayed very similar differences in water levels, typically around $0.2 \mathrm{ft}$. PZ-4 and PZ-4B showed the largest upwelling of water, with the deeper piezometer (PZ-4B) consistently having water-level elevations about $0.8 \mathrm{ft}$ higher than the water-level elevation in the shallow piezometer (PZ-4). All the water levels measured from greater depths were typically higher than those measured from shallower locations. Between PZ-3 and PZ-3B, the deeper piezometer (PZ-3B) typically had slightly higher water levels but there was more variability in the difference between the shallow and the deep piezometers, with water levels sometimes being nearly the same. PZ-3 and PZ-3B may have other factors affecting the hydrology such as soil type and geomorphology (for example, these paired piezometers are near a point bar on what appears to be a historical meander).

According to center pivot irrigation maps for Mason and Tazewell Counties, a total of 2,013 fields were identified as using center pivot irrigation, withdrawing an estimated volume of water exceeding 98 billion gallons (Bridges and Wilson, 2014); 1,553 of these systems were in Mason County, Ill., representing about 135,000 acres in the county (Imperial Valley Water Authority, 2019). The total acreage of farmland in Mason County is about 290,000 acres; therefore, about 47 percent of the farmland was utilizing irrigation in 2012 (U.S. Department of Agriculture, 2012). In 2017, the number of center pivot irrigation systems within the IVWA was 2,237 with an estimated 61.5 billion gallons of water removed from the aquifer during the irrigation season (Imperial Valley Water Authority, 2019). In 2018, the total number of irrigation systems increased to 2,252 , withdrawing an estimated total of about 52.5 billion gallons (table 2; Imperial Valley Water Authority, 2019).

From March to December 2017, about 33 in. of rain fell at gage nine, with the highest monthly rainfall occurring in July (6.92 in.). From May 24 to July 10, 2017, the area was in drought conditions, with only $0.81 \mathrm{in}$. of rain falling in about a 6-week period. This led to the highest monthly irrigation use, with about 22 billion gallons estimated to be used in 

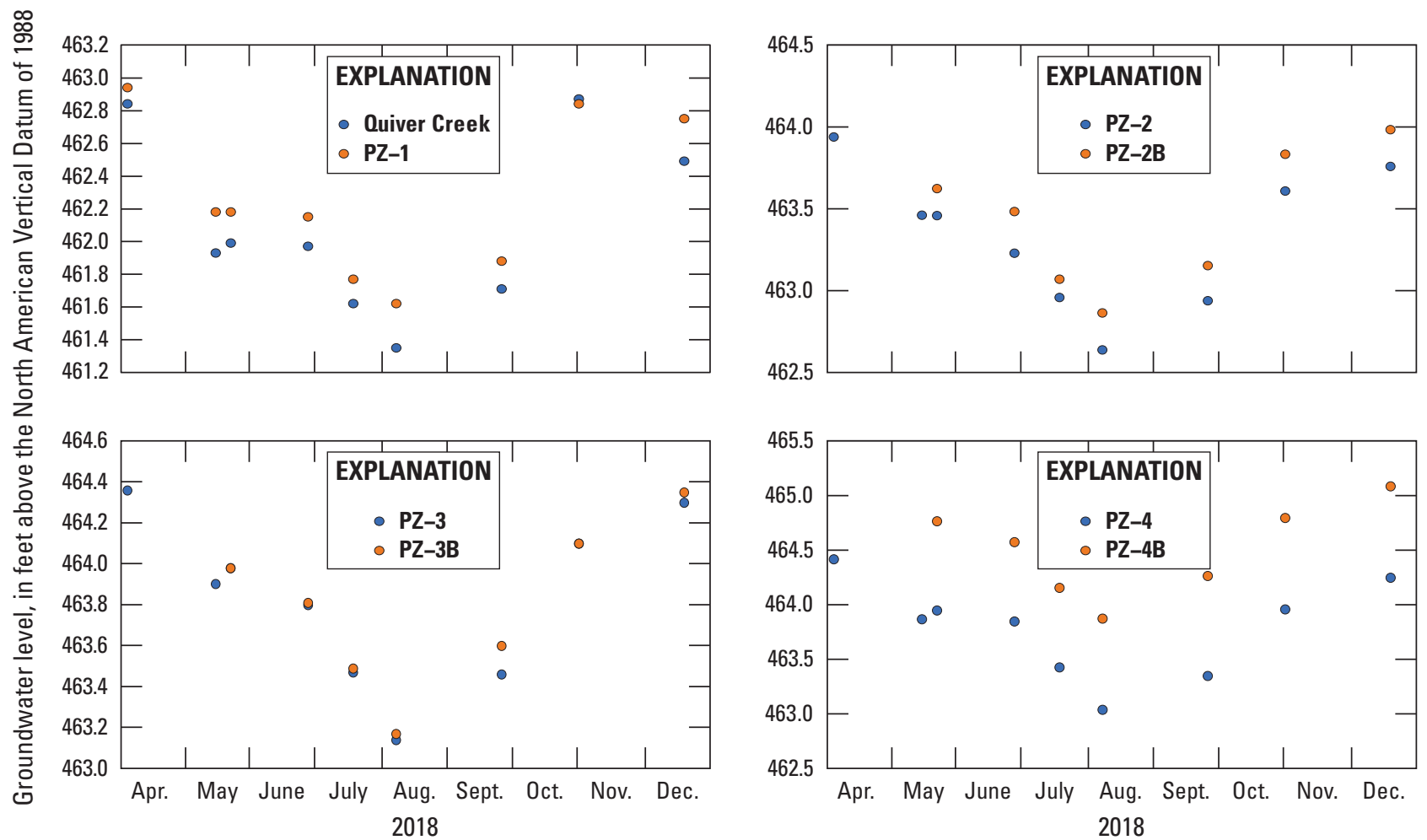

Figure 5. Groundwater elevations plotted for paired piezometers. Quiver Creek surface water with piezometer 1 (PZ-1), and the paired shallow and deep piezometers (PZ-2 and PZ-2B, PZ-3 and PZ-3B, and PZ-4 and PZ-4B).

June 2017. During 2018, the total precipitation was 40.26 in., with the highest monthly total of 6.92 in. occurring in August, and from January through March 2019, the total precipitation was 9.05 in. (fig. 4).

\section{Continuous Groundwater-Quality Data}

Continuous water-quality monitoring in the Havana well began on March 8, 2017. Data analysis for this report includes data collected from March 8, 2017, to March 31, 2019. Parameters that were continuously monitored were groundwater levels, nitrate, dissolved oxygen, specific conductance, water temperature, and $\mathrm{pH}$. Continuous monitoring (one reading every 15 minutes) allows for the collection of a larger dataset in comparison to periodic or event-based sampling and shows relations and trends that would otherwise be difficult to observe.

\section{Nitrate Concentrations}

Nitrate concentrations measured with the nitrate sensor ranged between 14.7 and $23.2 \mathrm{mg} / \mathrm{L}$ (fig. 6). Four discrete water-quality samples, collected after pumping the Havana well, verified the accuracy of the continuously measured nitrate concentrations (table 3). For all the discrete samples, the laboratory results verified the data recorded before pumping were within the accuracy of the sensor ( 3 percent), except for the April 4, 2018, sample when there was precipitation that may have caused some dilution of the well water during the discrete sampling process. There was some variability in nitrate concentrations during pumping, and the variability slightly exceeded the accuracy of the sensor one of the four times the well was pumped; the remaining times, variability was within sensor accuracy.

Generally, nitrate concentrations were stable or slowly declining during the fall and winter periods, with gradual increases through the spring and early summer, and brief pulses of very high nitrate during late winter/early spring. During the irrigation season, nitrate can fluctuate noticeably as a result of the complex interactions among irrigation, fertigation, plant metabolism, and precipitation. This fluctuation was observed more during the 2018 irrigating season. Method and timing of fertilizer application may be important to discerning the cause of the fluctuations; the fluctuations could be the result of adjacent field operations as the duration of peaks vary, and the rise and fall leading up to these peaks are quite rapid. Small spikes in nitrate, and dilution events, are seen during the nonirrigating season and are associated with rain events, often small enough that they are not evident during the irrigation season when more variables are affecting the subsurface hydrology and geochemistry. 


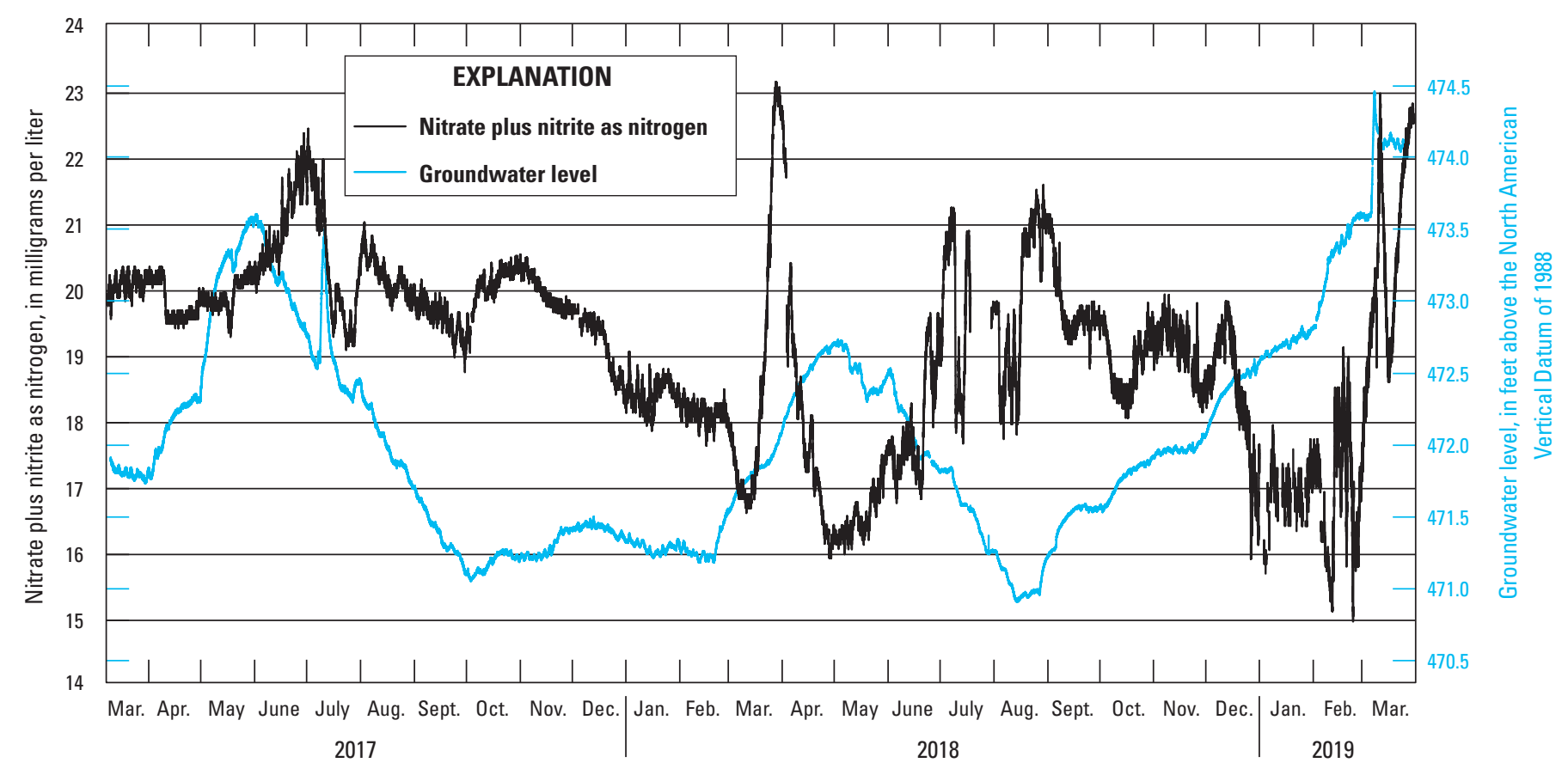

Figure 6. Nitrate concentration and groundwater elevation in feet above the North American Vertical Datum of 1988, March 8, 2017, to March 31, 2019, U.S. Geological Survey station 401913089534501.

Table 3. Summary of discrete water-quality results from the U.S. Geological Survey National Water Quality Laboratory analysis of nutrients.

[mg/L, milligram per liter; <, less than; - , not measured]

\begin{tabular}{lccccccc}
\hline Field identifier & Date & $\begin{array}{c}\text { Alkaline } \\
\text { persulfate as } \\
\text { nitrogen, } \\
\text { in } \mathbf{~ m g / L}\end{array}$ & $\begin{array}{c}\text { Ammonia, } \\
\text { in } \mathbf{~ m g / L}\end{array}$ & $\begin{array}{c}\text { Nitrite, } \\
\text { in } \mathbf{~ m g / L}\end{array}$ & $\begin{array}{c}\text { Ortho- } \\
\text { phosphate, } \\
\text { in } \mathbf{~ m g / L}\end{array}$ & $\begin{array}{c}\text { Nitrate plus } \\
\text { nitrite, as } \\
\text { nitrogen, } \\
\text { in } \mathbf{~ m g / L ~}\end{array}$ & $\begin{array}{c}\text { Continuously measured } \\
\text { nitrate plus nitrite, as } \\
\text { nitrogen, prior to sample } \\
\text { collection, in } \mathbf{~ m g / L ~}\end{array}$ \\
\hline Havana Well & $4 / 11 / 2017$ & 20.4 & $<0.01$ & 0.00705 & 0.0352 & 19.9 & 19.6 \\
Havana Well & $6 / 13 / 2017$ & 21.4 & 0.0103 & 0.00433 & 0.0266 & 20.1 & 20.7 \\
Havana Well & $10 / 3 / 2017$ & 19.4 & $<0.01$ & 0.0054 & 0.0244 & 19.7 & 19.4 \\
Havana Well & $4 / 4 / 2018$ & - & - & - & - & 20.7 & 21.9 \\
\hline
\end{tabular}

Nitrate concentrations were evaluated with respect to groundwater levels, precipitation, and estimated irrigation usage for the study period (fig. 6). The relation between groundwater levels and nitrate were temporally variable during the monitoring period and appear to be affected by the method of fertilizer application and the intensity of irrigation usage. The nitrate concentrations were largest during relatively short periods of time. The two periods of greatest observed continuous nitrate concentrations were 23.2 and $22.4 \mathrm{mg} / \mathrm{L}$ on March 28, 2018, and March 11, 2019, respectively. On March 24-25, 2018, a total of 1.90 in. of rain was recorded at IVWA gage nine prior to the peak on March 28, 2018. Similarly, on March 9, 2019, 1.75 in. of rain was recorded prior to the observed peak on March 11, 2019. These elevated nitrate concentrations may be related to physical application where nitrate is directly flushed into the groundwater by precipitation and (or) snowmelt. Roadcap and others (2002) discuss physical application occurring in March, April, and June. Besides these shorter-lived large peaks, gradual increases in nitrate concentrations were observed in late winter and early spring. Additionally, although exact days were unknown, in 2018, the Mason State Tree Nursery physically applied nitrate in fields located south and southwest of the continuous monitoring well beginning in late June through August. Two of the fields received four applications and one field received one application. Immediately after fertilizer application about a 
half inch of irrigation water is broadcast over the fertilizer (G. Rampley, Mason State Tree Nursery, written commun., 2019). On June 21-22, 2018, 1.07 in. of rain was recorded at IVWA gage nine and coincided with nitrate concentrations beginning to increase. Practices at the tree nursery may play a role in the more variable concentrations seen at the Havana well in the 2018 peak irrigation season; some of this variability is driven by precipitation events and some does not coincide with precipitation and may be related to fertigation or irrigation.

A gradual decline in water levels is observed in spring 2017 and 2018; although this is something that would occur naturally through evapotranspiration, it is presumed to be affected by irrigation pumping as air temperatures begin to rise and plants require more water for growth and productivity, placing more demands on the aquifer. Through the late spring and early summer of 2017 and 2018, nitrate concentrations consistently increased and typically peaked several weeks after the start of declining water levels. Following these peaks, nitrate concentrations held relatively steady or slowly decreased through late summer, fall, and winter.

The effect of nonfertilized water infiltrating the surface from a ditch near the well was observed in early July 2017 as a result of a 5-week drought from late May to June 2017. The ditch was located about $40 \mathrm{ft}$ from the well and nonfertilized irrigation water was pumped into the ditch; the response was a spike in water levels in the Havana well that was observed within hours of the start of pumping into the ditch. The flooding of the ditch occurred from July 7-9 and the noticeable and rapid increase in water levels at this time was a direct effect of the ditch flooding. The induced flooding of the ditch diluted nitrate concentrations appreciably for a period of about 2 weeks. After this 2-week period, nitrate concentrations returned to the gradually decreasing levels observed prior to dilution.

\section{Dissolved Oxygen}

Dissolved oxygen was assessed in relation to nitrate concentrations for the study period (fig. 7). During the period of monitoring, dissolved oxygen ranged from 2.3 to $7.5 \mathrm{mg} / \mathrm{L}$. As mentioned in McCallen and others (2008), a dissolved oxygen concentration of $2.0 \mathrm{mg} / \mathrm{L}$ is a common threshold for denitrification to occur, and below this concentration denitrification becomes more favorable. Dissolved oxygen concentrations observed at the monitoring well during the period of monitoring were too high to promote denitrification, which leads to the persistence of nitrate in the shallow groundwater. Dissolved oxygen concentrations were erratic while increasing during much of the irrigation season, with concentrations peaking in late summer or early fall and then generally declining through the fall and winter. The lowest values were during late spring and early summer.
Variability in dissolved oxygen concentrations seems to be affected by irrigation operations. Fluctuations in dissolved oxygen concentrations are much more noticeable beginning in early spring and are especially apparent when the water table begins to decline. Throughout the irrigation season, dissolved oxygen concentrations are erratic. Generally, concentrations begin to stabilize in late summer and early fall, then gradually decrease throughout fall and winter. It is apparent that the irrigation season is affecting dissolved oxygen concentrations in the aquifer, but it is uncertain what may be driving this relation; this may be caused by irrigation water being oxygenated during pumping and delivery through the centerpivot irrigation systems. In the 2017 growing season, drought conditions were prevalent, with only 0.81 in. of rain recorded at the nearby IVWA rain gage nine over about a 6 -week period from May 24 to July 10, where the maximum irrigation usage was observed during June 2017. This observation was during a time when some of the highest estimated irrigation withdrawals occurred; based on monthly records, June 2017 had the maximum estimated irrigation usage. About 1.7, 22.0, and 17.3 billion gallons of water were used in May, June, and July 2017, respectively. About 16.0, 19.3, and 8.7 billion gallons of water were used in May, June, and July 2018, respectively (Imperial Valley Water Authority, 2019; table 2).

Dissolved oxygen and nitrate usually were positively related, but in 2017 during the irrigation season and shortly after the water table began to decline the inverse was observed (figs. 7 and 8). During the 2018 irrigation season when water levels began to decline, the positive relation did not change, which was the opposite to what was observed in 2017 (figs. 7 and 9). The collection of empirical irrigation data with better temporal and spatial resolution, along with additional continuous data at the well, would help cover more environmental extremes, which would help in understanding what may be causing these fluctuations.

Flooding of the ditch near the well caused the lowest dissolved oxygen concentrations in the record. This unfertilized irrigation water was piped to the ditch and not delivered through a sprinkler system, which would presumably oxygenate the water in the process of delivery. This water was pumped from deeper in the aquifer where water tends to be anoxic (Chapelle, 1993). Kelly (1997) observed a redoxcline at the Mason State Tree Nursery at a depth of around 40 feet, which was characterized by little to no nitrate and dissolved oxygen. A change in the color of the sand from reddish brown to gray around this depth indicates that iron is being reduced, which occurs under conditions more reducing than nitrate reduction reactions (Kelly, 1997). In the process of pumping and delivering, the water was probably oxygenated, but likely not to the extent that a sprinkler system would oxygenate the water. Additional data covering more environmental extremes are needed to better understand the role of irrigation and precipitation and how those factors may affect the relation between nitrate and dissolved oxygen. 


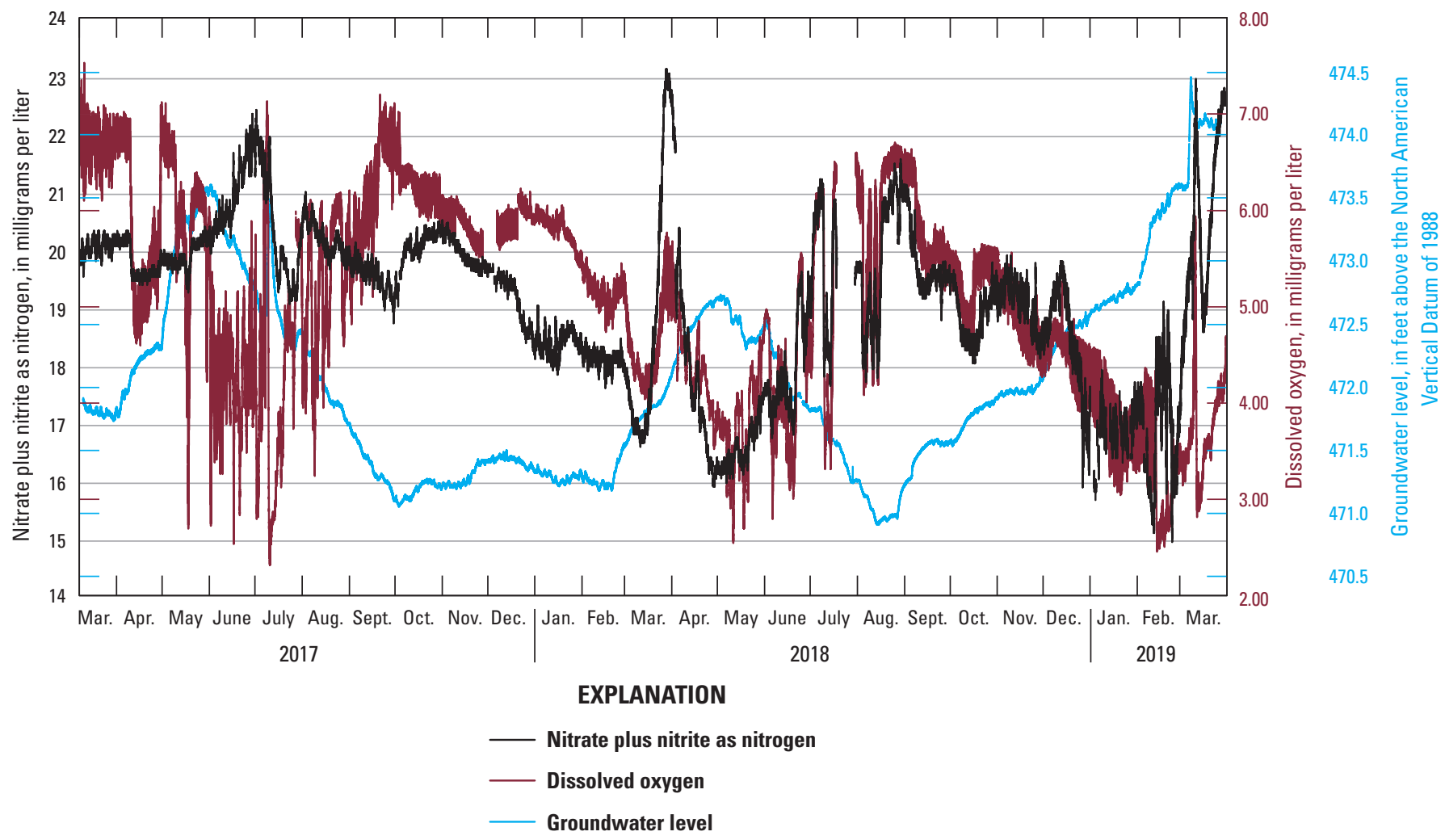

Figure 7. Nitrate concentration, dissolved oxygen, and groundwater elevation in feet above the North American Vertical Datum of 1988, March 8, 2017, to March 31, 2019, U.S. Geological Survey station 401913089534501.
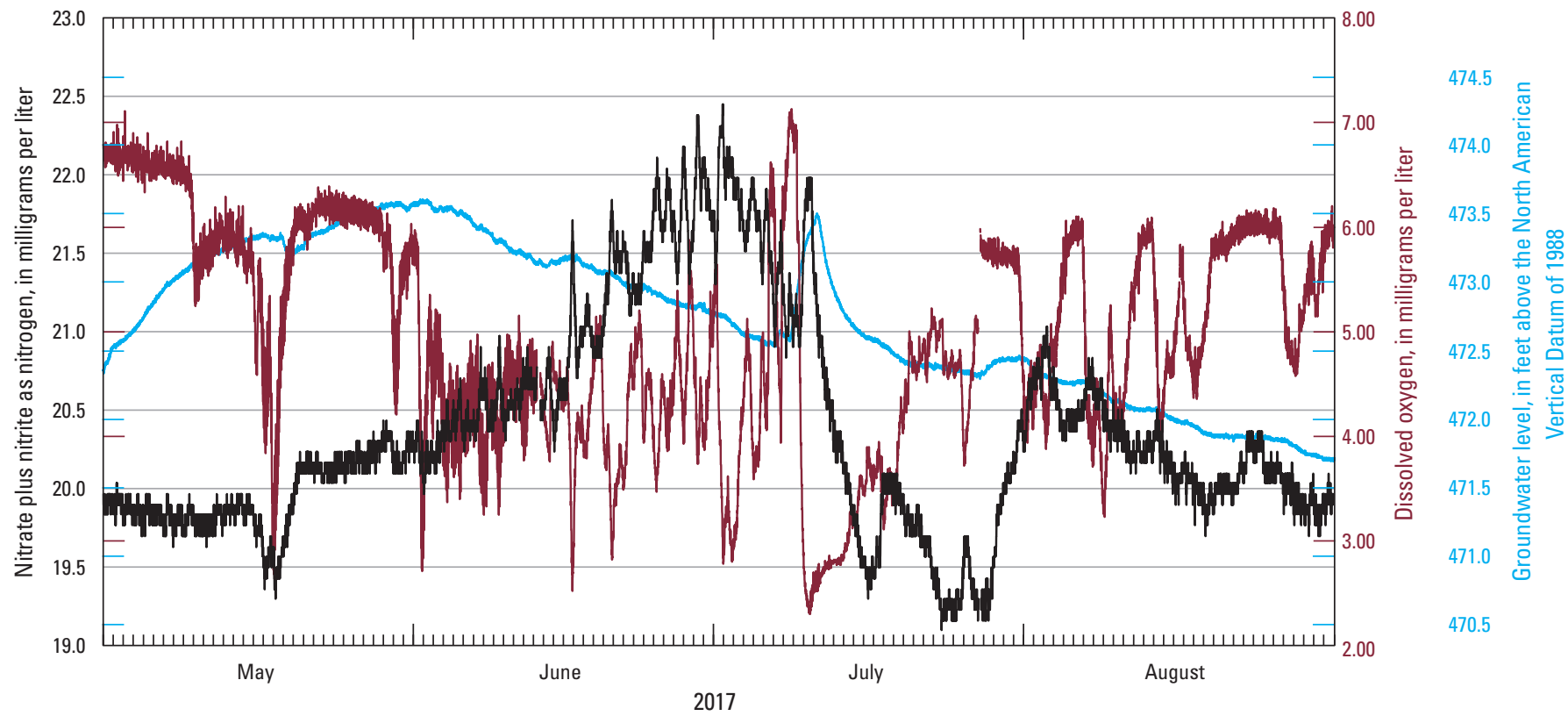

EXPLANATION

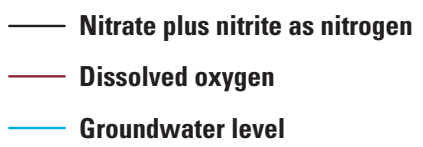

Figure 8. Nitrate concentration, dissolved oxygen, and groundwater elevation in feet above the North American Vertical Datum of 1988, during 2017 peak irrigation period, May 1 to August 31, U.S. Geological Survey station 401913089534501. 


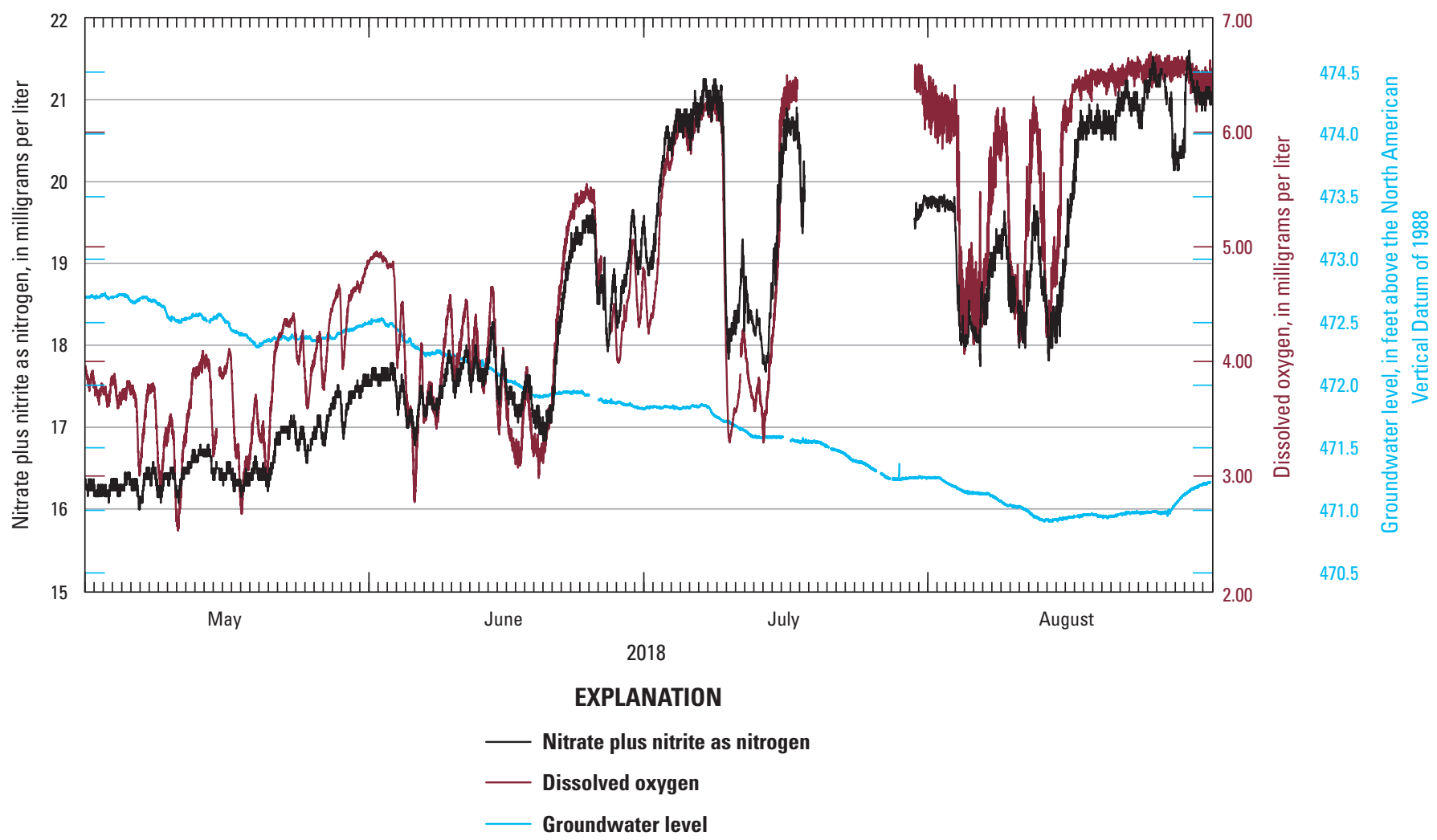

Figure 9. Nitrate concentration, dissolved oxygen, and groundwater elevation in feet above the North American Vertical Datum of 1988, during 2018 peak irrigation period, May 1 to August 31, U.S. Geological Survey station 401913089534501.

\section{Specific Conductance}

Specific conductance during the period of monitoring ranged from 500 to 665 microsiemens per centimeter at 25 degrees Celsius $\left(\mu \mathrm{S} / \mathrm{cm}\right.$ at $\left.25^{\circ} \mathrm{C}\right)$ and was generally stable until irrigation began. It appears irrigation practices may cause considerable variability in specific conductance through infiltration of irrigation water from the surface to the shallow groundwater. This variability is most pronounced during the peak irrigation season, when estimated irrigation withdrawals are the highest. Although there is variability in the data, there is a range from about 500 to $560 \mu \mathrm{S} / \mathrm{cm}$ at $25^{\circ} \mathrm{C}$ that appears to be reflective of the system when it is not affected by irrigation. Specific conductance often returns to this range of values, especially during much of the fall and winter, but also during the spring, and more rarely during the summer (fig. 10). Irrigation can occur throughout the growing season and even leading into fall, but September is the last month for which the IVWA compiles estimated irrigation usage data (table 2).

Specific conductance variation during the nongrowing season was minimal and generally positively related to nitrate. This relation changed between the 2017 and 2018 irrigation season. During the growing season in 2017, especially in June and July, a positive relation between nitrate concentrations and specific conductivity was observed. This positive relation may be related to irrigation driving constituents, including nitrate, down through the soils to the shallow groundwater (fig. 11). Specifically, when the deeper groundwater used for irrigation is infused with water-soluble fertilizer, the frequency and intensity of these applications may be substantial in driving this relation. These positive relations were mostly observed during a period of drought, with a total of $0.81 \mathrm{in.} \mathrm{of}$ rainfall occurring from May 24 to July 10, 2017. During this period no daily rainfall exceeded 0.1 in., except for June 20 when 0.46 in. of rain was recorded. The opposite relation was observed in 2018 when there was more substantial rainfall and less estimated irrigation usage (fig. 12). Additional continuous data that cover more environmental extremes would be helpful in further understanding the relation between nitrate and dissolved oxygen. Improved temporal and spatial resolution on irrigation usage data would also be helpful to better understand how irrigation may affect relations between these data.

\section{Water Temperature}

Water temperature during the period of monitoring ranged from 12.2 to 13.9 degrees Celsius (fig. 13). Temperatures fluctuated annually, with the coldest groundwater temperatures recorded in the middle of summer and the warmest recorded in the middle of winter. Temperature data were also observed to be affected by precipitation, irrigation, 

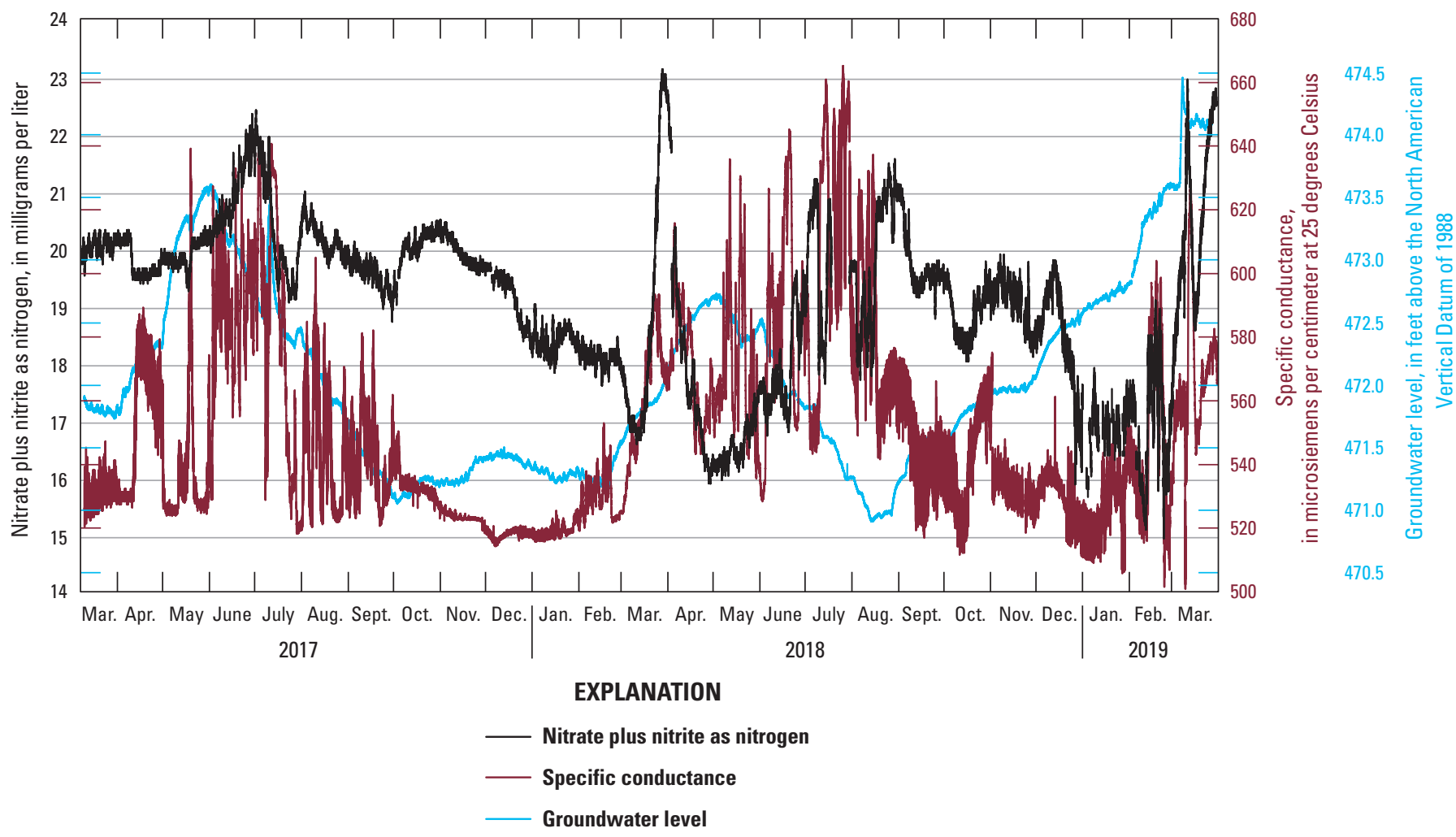

Figure 10. Nitrate concentration, specific conductance, and groundwater elevation in feet above the North American Vertical Datum of 1988, March 8, 2017, to March 31, 2019, U.S. Geological Survey station 401913089534501.
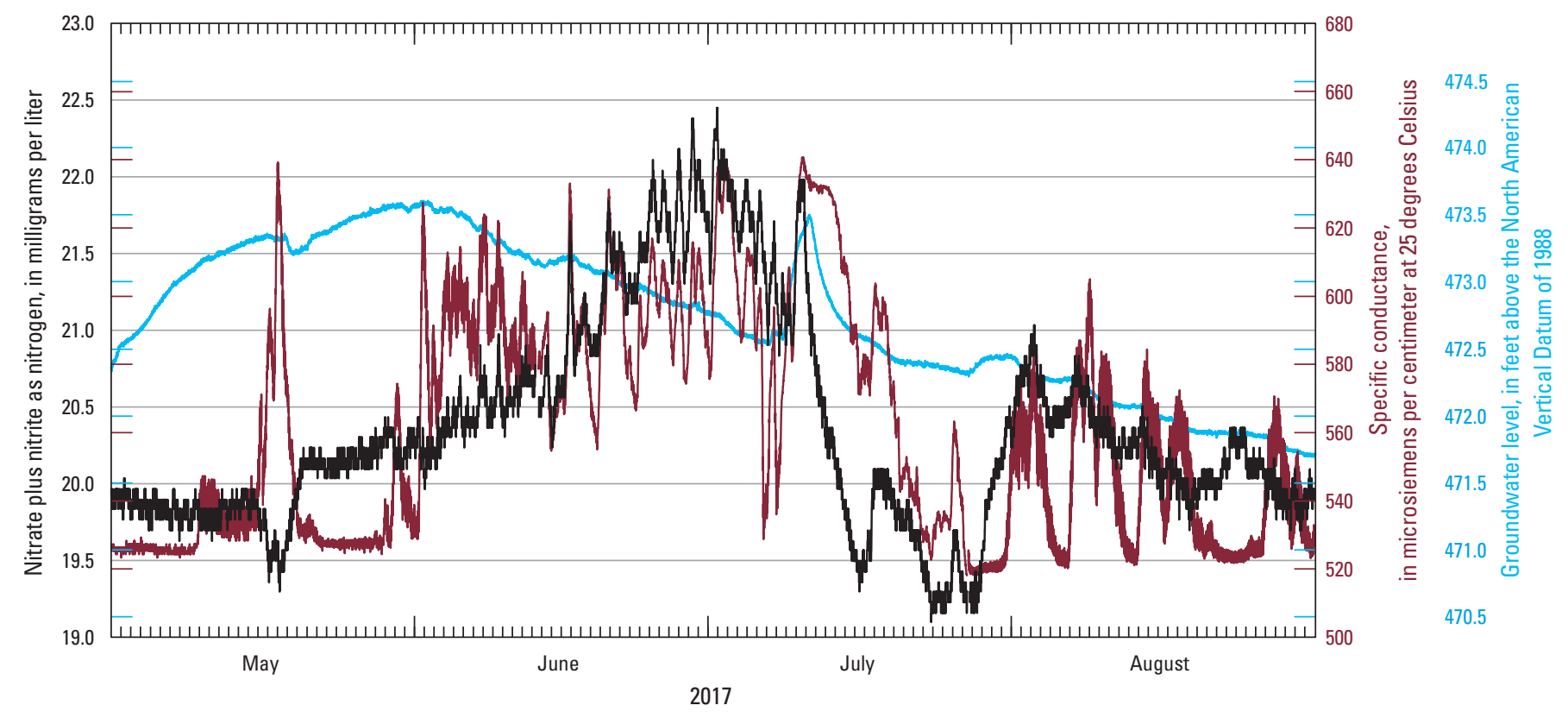

EXPLANATION

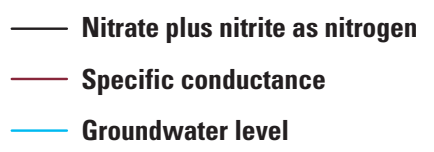

Figure 11. Nitrate concentration, specific conductance, and groundwater elevation in feet above the North American Vertical Datum of 1988, during 2017 peak irrigation period, May 1 to August 31, U.S. Geological Survey station 401913089534501. 

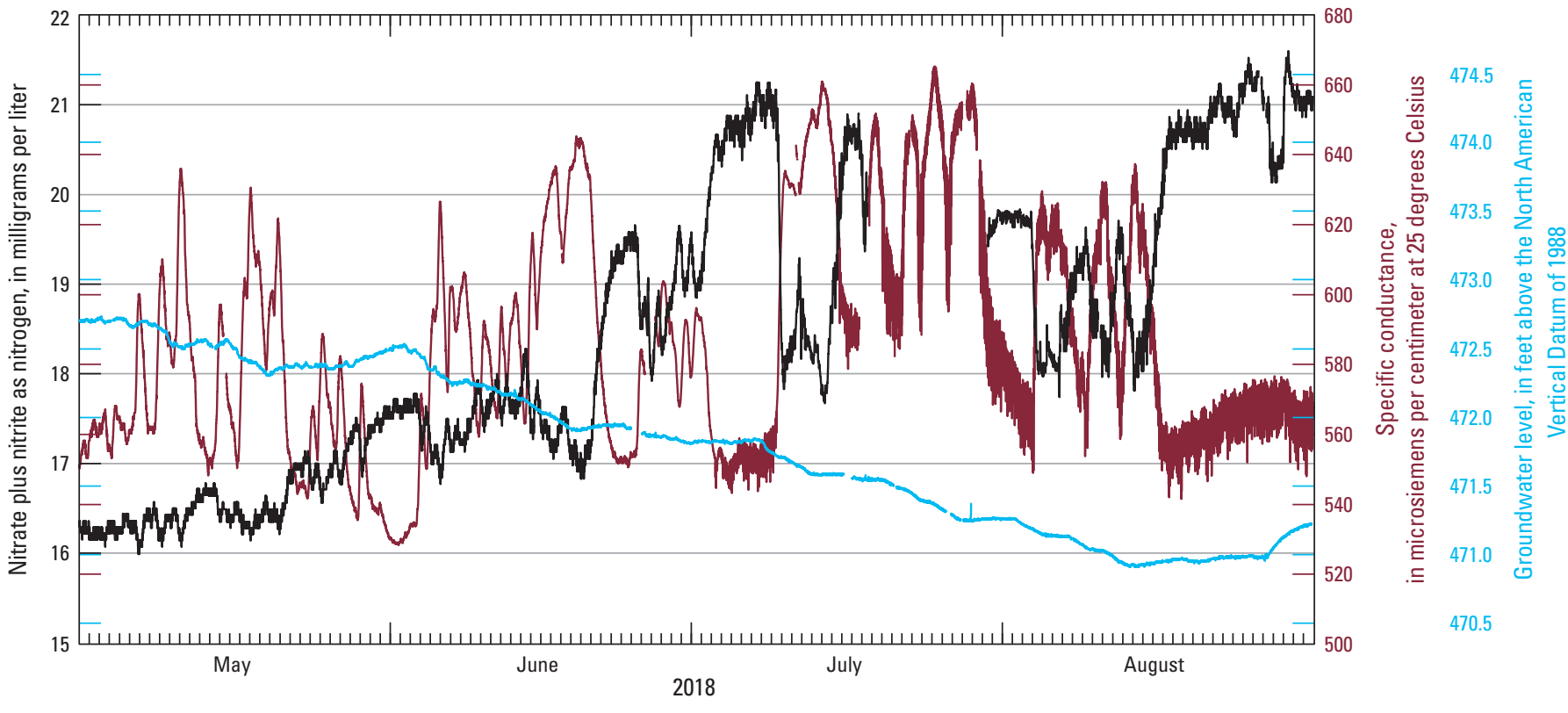

EXPLANATION

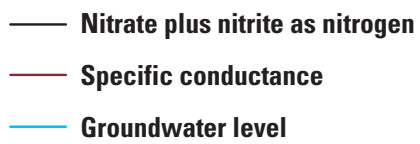

Figure 12. Nitrate concentration, specific conductance, and groundwater elevation in feet above the North American Vertical Datum of 1988, during 2018 peak irrigation period, May 1 to August 31, U.S. Geological Survey station 401913089534501.

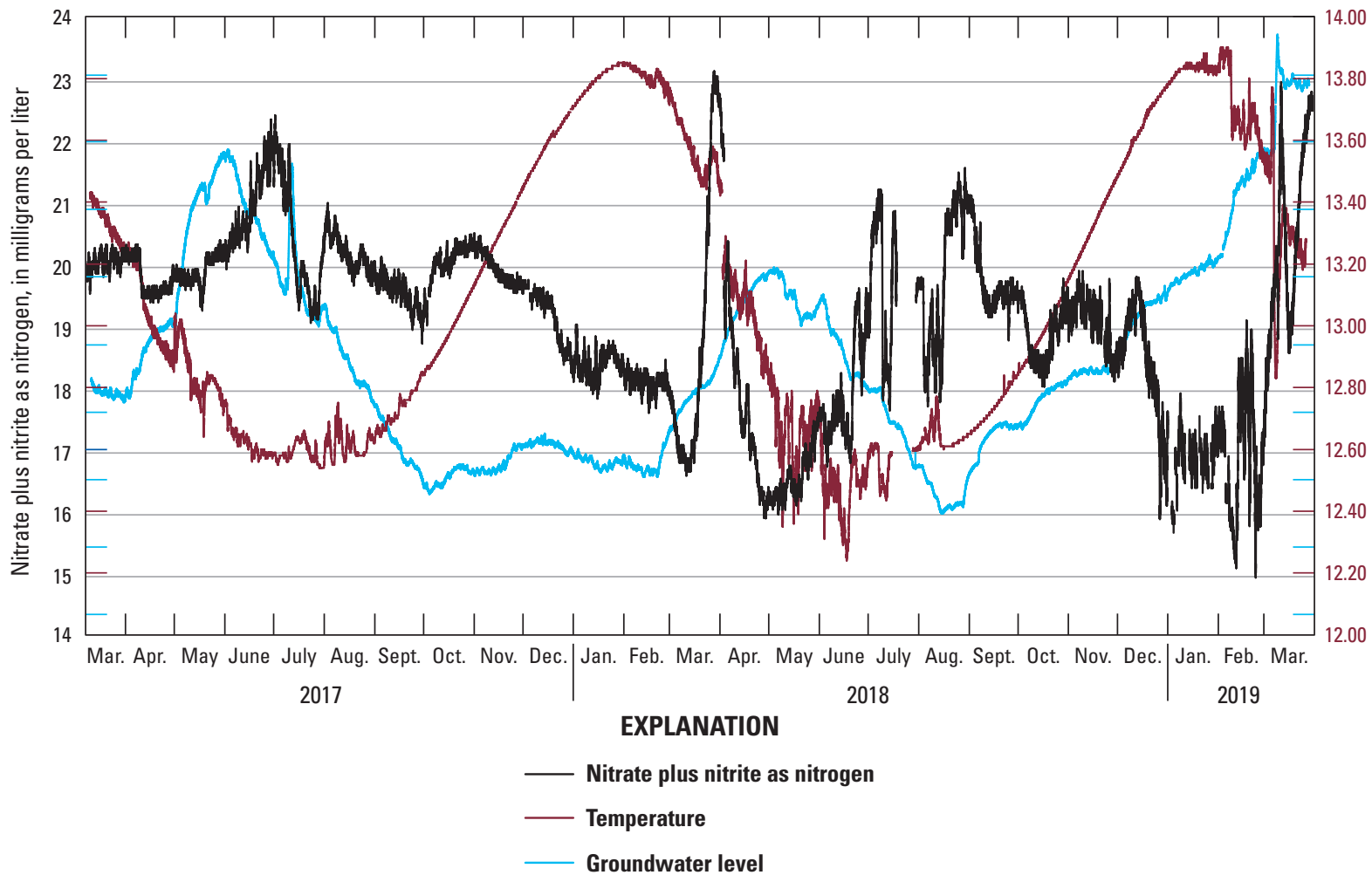

Figure 13. Nitrate concentration, temperature, and groundwater elevation in feet above the North American Vertical Datum of 1988, March 8, 2017, to March 31, 2019, U.S. Geological Survey station 401913089534501. 
or snowmelt. The effect of precipitation and irrigation was especially noticeable during the growing season. During the 2018 growing season, temperature changes coincided with groundwater-level declines, indicating that temperature is linked to irrigation intensity. A possible explanation for this is the presumably colder irrigation water being pulled from deeper within the aquifer and delivered at the surface with a portion of it rapidly infiltrating and returning to the shallow groundwater.

No general relation between nitrate and temperature was visually observed. Small variations in temperature are interpreted to be the result of large inputs from either precipitation, irrigation, or snowmelt. Many of the variations can be associated with rainfall; however, temperature spikes at other times in the record were not so readily defined by precipitation events, with these temperature variations most probably attributed to irrigation practices. Temperature variations were much more subdued during the fall and winter months, when there were less precipitation and irrigation, and became more dynamic in late winter driven by snowmelt, precipitation, and warming air temperatures.
pH

Values for $\mathrm{pH}$ ranged from 7.1 to 8.0 standard $\mathrm{pH}$ units during the period of monitoring (fig. 14). Although $\mathrm{pH}$ showed considerable variability during the period of record, there were no obvious relations with irrigation or precipitation; however, there does tend to be more fluctuation in $\mathrm{pH}$ during times when there is irrigation usage. The flooding of the ditch in July 2017 produced a noticeable decrease in $\mathrm{pH}$, and similar decreases were also observed when groundwater levels began to decrease in 2017 and 2018.

Larger and smaller scale fluctuations of $\mathrm{pH}$ generally related positively with nitrate; however, at times this relation was negative, and at other times there did not seem to be any relation between the two parameters. Considering the small range of $\mathrm{pH}$ values, it does not appear $\mathrm{pH}$ is a substantial factor in this system especially regarding nitrate dynamics.

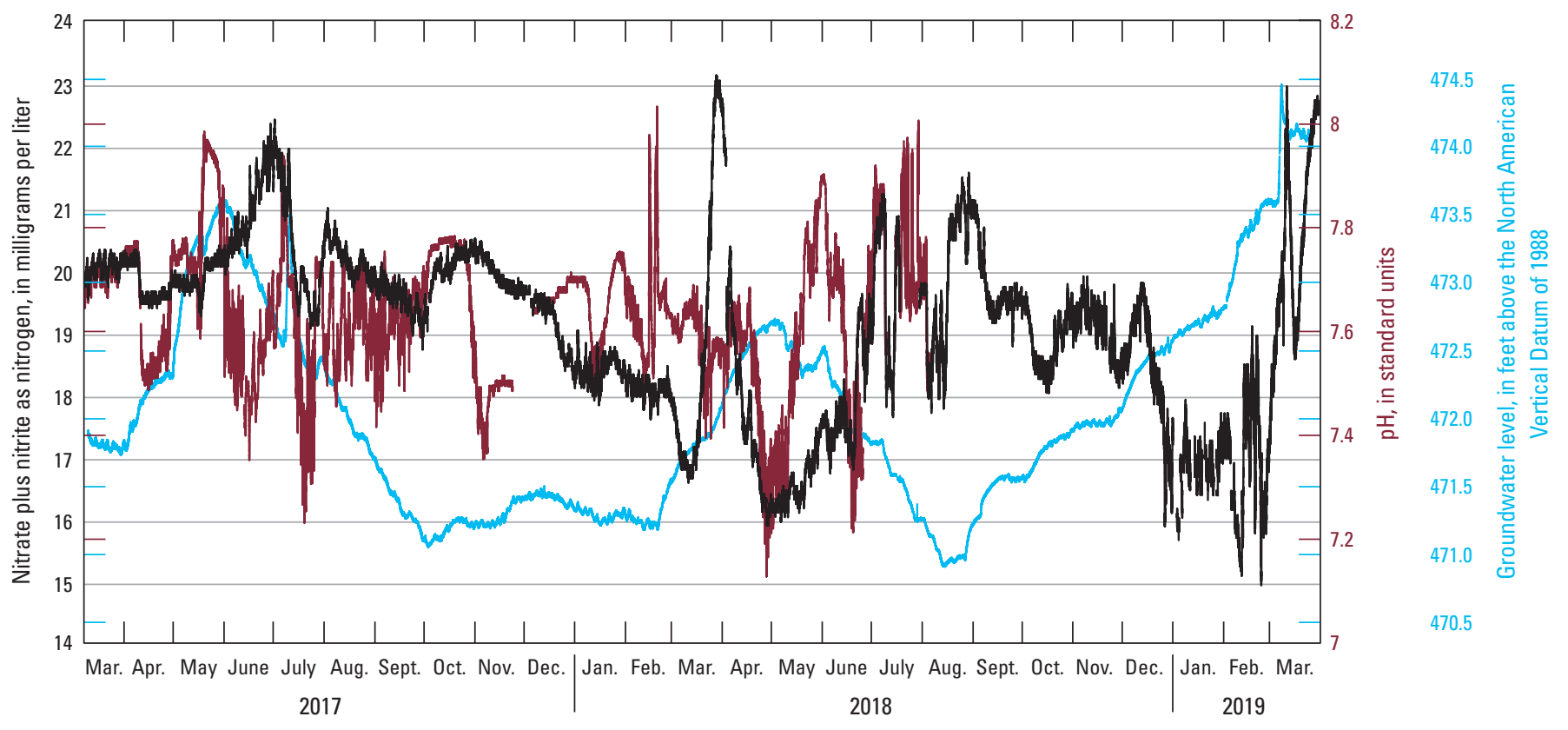

EXPLANATION

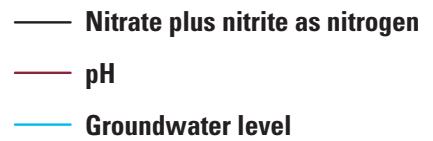

Figure 14. Nitrate, $\mathrm{pH}$, and groundwater elevation in feet above the North American Vertical Datum of 1988, March 8, 2017, to March 31, 2019, U.S. Geological Survey station 401913089534501. 


\section{Characterization of Water Quality in Quiver Creek Stream and Floodplain}

\begin{abstract}
During visits to the Havana well, instantaneous field measurements of water quality and water levels were made in the Quiver Creek surface water. From April 11, 2017, to March 31, 2019, 29 instantaneous measurements of nitrate concentrations ranged from less than 0.1 to $6.4 \mathrm{mg} / \mathrm{L}$. Beginning on April 3, 2018, instantaneous measurements of dissolved oxygen, specific conductance, water temperature, and $\mathrm{pH}$ were made, with instantaneous water levels started on April 4, 2018. During the time when these measurements were being made, dissolved oxygen concentrations ranged
\end{abstract} from 7.4 to $12.2 \mathrm{mg} / \mathrm{L}$, specific conductance ranged from 470 to $711 \mu \mathrm{S} / \mathrm{cm}$ at $25^{\circ} \mathrm{C}$, water temperature ranged from 1.7 to 22.0 degrees Celsius, $\mathrm{pH}$ ranged from 6.1 to 8.1 standard units, and water-level elevations ranged from 461.35 to $464.22 \mathrm{ft}$ (table 4).

Nitrate concentrations in Quiver Creek were much less than those observed in groundwater at the Havana well. Concentrations in Quiver Creek were typically low during irrigating season and increased during winter, early spring, after precipitation events, and in general during periods of recharge (fig. 15). Seasonally, this is similar to what was found in Murphy and others (2013); however, in Layne Hydro (2012), the flow of Quiver Creek was documented to consist of almost entirely of groundwater. Data collected for this study indicate that under base-flow conditions the source water is the deeper groundwater with lower concentrations of nitrate, and during nonbase-flow conditions more of the shallow groundwater with higher concentrations of nitrate is contributing to Quiver Creek. In 2017, a drier year with more estimated irrigation usage, the low nitrate concentrations continued into winter, but in 2018, when there was above average rainfall and less estimated irrigation usage, there were higher concentrations of nitrate in Quiver Creek during the same time period. Some of the highest nitrate concentrations were measured following rain events and snowmelt; for example, on October 31, 2018 , when a nitrate concentration of $1.9 \mathrm{mg} / \mathrm{L}$ was measured, about $1 \mathrm{in}$. of rain was recorded at precipitation gage nine that evening, and the next morning the water level in Quiver Creek had risen about $0.5 \mathrm{ft}$ and a nitrate concentration of $5.7 \mathrm{mg} / \mathrm{L}$ was measured. Water levels in Quiver Creek and in PZ-1 were measured from the measuring point (top of casing) on PZ-1. When PZ-1 was overtopped, water levels could not be measured because the water was too deep to wade into. This was the only time that water levels in Quiver Creek were observed to be higher than those in the piezometer beneath the bed of the stream (fig. 5). During recharge events like the one on October 31, 2018, shallow groundwater with high nitrate concentration was readily entering the surface water. It is also important to note that this recharge event was during a period of little to no irrigation. This relation between groundwater levels, Quiver Creek water levels, and increased nitrate concentrations is difficult to understand without higher frequency data in the piezometers and the Quiver Creek surface water. Water-quality and hydrologic data indicate that during much of the peak irrigation season, Quiver Creek predominantly consists of the deeper low-nitrate Mahomet aquifer water, whereas during other periods there is more substantial input from the higher-nitrate shallow groundwater, especially during recharge periods, whether from precipitation and (or) snowmelt.

Observed ranges of nitrate, specific conductance, dissolved oxygen, temperature, $\mathrm{pH}$, and water-level elevations for Quiver Creek and the series of piezometers are shown in table 4. In general, the shallow piezometers showed nitrate concentrations decreased towards Quiver Creek (fig. 16). Concentrations were consistently high at $\mathrm{PZ}-4$ at the toe of the upland slope towards the nursery. Nitrate concentrations in PZ-4 ranged from 16.4 to $22.7 \mathrm{mg} / \mathrm{L}$. PZ-3 showed considerably less nitrate than $\mathrm{PZ}-4$, with nitrate concentrations ranging from 7.6 to $13.6 \mathrm{mg} / \mathrm{L}$. PZ-2 was in the Quiver Creek streambank and concentrations ranged from less than 0.1 to $8.3 \mathrm{mg} / \mathrm{L}$. PZ-1, beneath the Quiver Creek streambed, never had a detection of nitrate consistently measuring less than $0.1 \mathrm{mg} / \mathrm{L}$.

The deeper piezometers ( $\mathrm{PZ}-2 \mathrm{~B}, \mathrm{PZ}-3 \mathrm{~B}$, and $\mathrm{PZ}-4 \mathrm{~B})$ were paired with the shallow piezometers as closely as possible to assess vertical variation in groundwater levels and water quality. The deeper piezometers typically showed much less nitrate except for $\mathrm{PZ}-3 \mathrm{~B}$, which showed elevated nitrate concentrations ranging from 6.3 to $9.4 \mathrm{mg} / \mathrm{L}$. PZ-2B, located deeper in the bank, did not have detectable nitrate concentrations and always measured less than $0.1 \mathrm{mg} / \mathrm{L}$. PZ-4B also consistently measured less than $0.1 \mathrm{mg} / \mathrm{L}$, except on one occasion when $0.1 \mathrm{mg} / \mathrm{L}$ was measured.

PZ-3 and PZ-3B showed little to no variation in waterlevel differences and was also the only location that consistently showed nitrate concentrations present in the shallow and deep piezometers, although concentrations were consistently lower in the deeper piezometer. This location appears to be near the point bar of a historical meander or former oxbow, presumed to be predevelopment. It is possible that this area readily receives greater amounts of recharge from the nearby and regularly disturbed soil (crop cultivation) and (or) there is less organic material in this area and accumulated sand deposits have created a preferential flow path capable of carrying nitrate deeper in the aquifer before any denitrification or substantial mixing can occur. The other deeper piezometers (PZ-1, PZ-2B, and PZ-4B) did not have detections of nitrate above $0.1 \mathrm{mg} / \mathrm{L}$, which may be because of vertical hydraulic controls limiting the downward movement of groundwater. These wells may also experience natural denitrification, presumably from mixing with the deeper anoxic groundwater with very little to no nitrates. Roadcap and others (2002) also documented a combination of mixing and partial denitrification at the Mason State Tree Nursery by sampling a nest of multilevel sampling wells. Low levels of nitrate at depth have been observed numerous times in unconfined aquifers because conditions at depth promote denitrification (Kelly, 1997). Kelly (1997) identified a redoxcline and below it the redox 
Table 4. Range of instantaneous measurements of water quality and water-level elevations, April 11, 2017, to February 5, 2019, Mason County, Illinois.

[mg/L, milligram per liter; $\mu \mathrm{S} / \mathrm{cm}$, microsiemen per centimeter; ${ }^{\circ} \mathrm{C}$, degrees Celsius; NAVD 88; North American Vertical Datum of 1988; <, less than]

\begin{tabular}{|c|c|c|c|c|c|c|c|}
\hline Field identifier & $\begin{array}{l}\text { Number of } \\
\text { instantaneous } \\
\text { readings }\end{array}$ & $\begin{array}{l}\text { Range of nitrate as } \\
\text { nitrogen, in } \mathrm{mg} / \mathrm{L}\end{array}$ & $\begin{array}{l}\text { Range of dissolved } \\
\text { oxygen concentrations, } \\
\text { in } \mathrm{mg} / \mathrm{L}\end{array}$ & $\begin{array}{l}\text { Range of specific con- } \\
\text { ductance, in } \mu S / c m\end{array}$ & $\begin{array}{l}\text { Range of water } \\
\text { temperature, in }{ }^{\circ} \mathrm{C}\end{array}$ & $\begin{array}{l}\text { Range of } \mathrm{pH} \text {, } \\
\text { in pH units }\end{array}$ & $\begin{array}{c}\text { Range of water levels, } \\
\text { above NAVD } 88\end{array}$ \\
\hline Quiver Creek & 28 & $<0.1-6.4$ & $* 7.4-12.2$ & $* 470-711$ & $* 1.7-22.0$ & $* 6.1-8.1$ & $* * 461.35-464.22$ \\
\hline PZ-1 & 9 & $<0.1$ & $<0.1-1.0$ & $560-648$ & $10.5-15.2$ & $7.1-7.7$ & $461.00-462.94$ \\
\hline PZ-2 & 9 & $<0.1-8.3$ & $<0.1-1.9$ & $549-639$ & $12.0-15.9$ & $6.9-7.3$ & $461.40-463.94$ \\
\hline PZ-2B & 7 & $<0.1$ & $<0.1-0.1$ & $580-648$ & $13.3-14.4$ & $7.2-7.7$ & $462.03-463.98$ \\
\hline PZ-3 & 9 & $7.6-13.6$ & $0.2-0.5$ & $612-728$ & $6.9-20.4$ & $6.4-7.3$ & $462.05-464.36$ \\
\hline$P Z-3 B$ & 7 & $6.3-9.4$ & $1.8-6.0$ & $520-567$ & $12.0-17.1$ & $6.9-7.4$ & $463.17-464.35$ \\
\hline $\mathrm{PZ}-4$ & 9 & $16.4-22.7$ & $2.2-6.2$ & $571-725$ & $8.5-17.4$ & $6.4-7.3$ & $463.04-464.42$ \\
\hline$P Z-4 B$ & 7 & $<0.1-0.1$ & $<0.1-0.6$ & $623-636$ & $12.4-15.1$ & $6.5-7.2$ & $463.84-465.08$ \\
\hline
\end{tabular}

*16 instantaneous readings.

**15 instantaneous readings. 


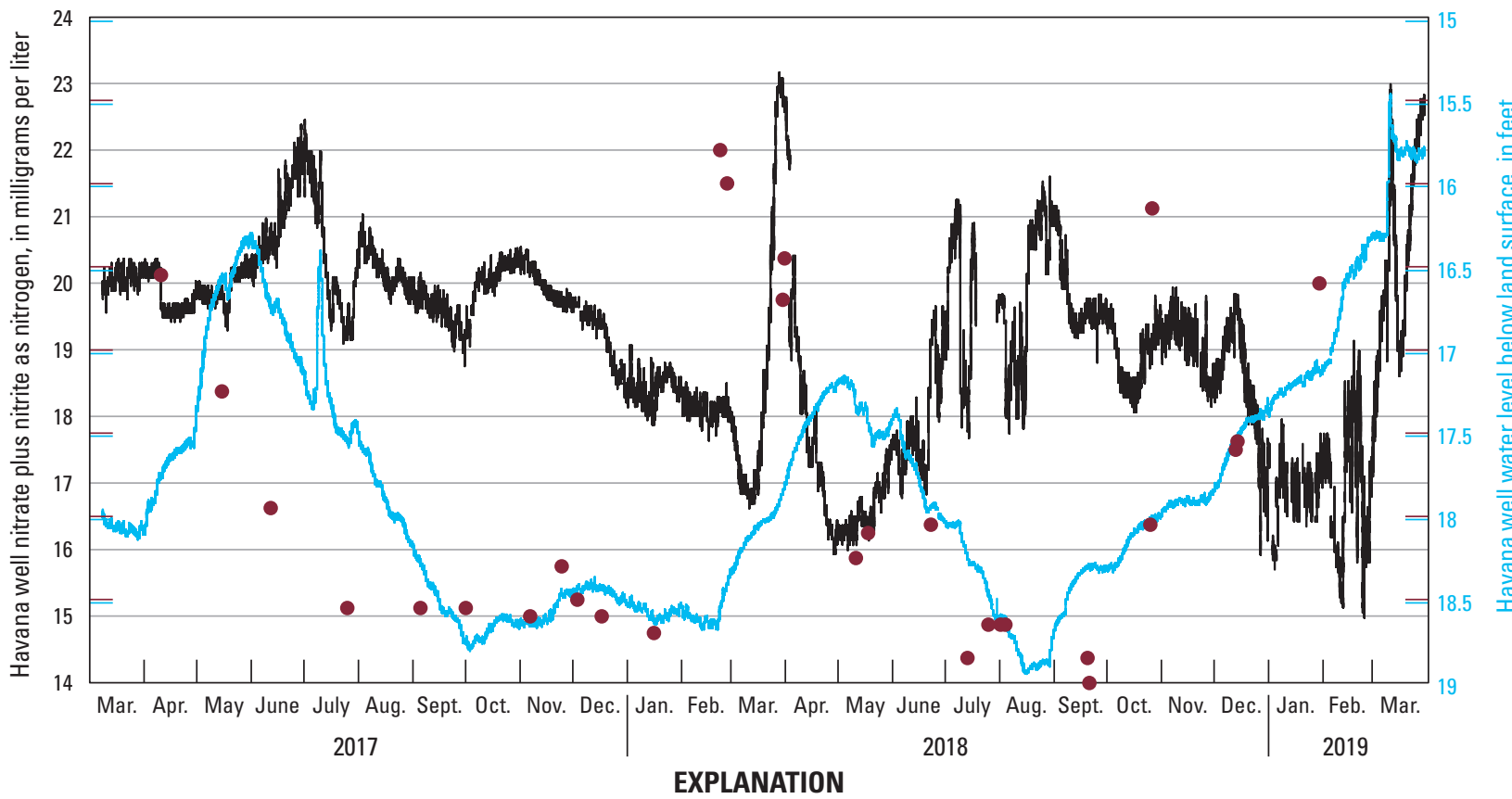

8
7
7

\section{EXPLANATION}

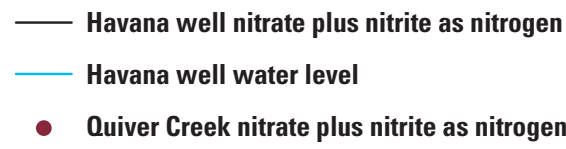

Figure 15. Continuous groundwater levels and groundwater nitrate concentrations at U.S. Geological Survey station 401913089534501, plotted with instantaneous measurements of nitrate in Quiver Creek surface water.

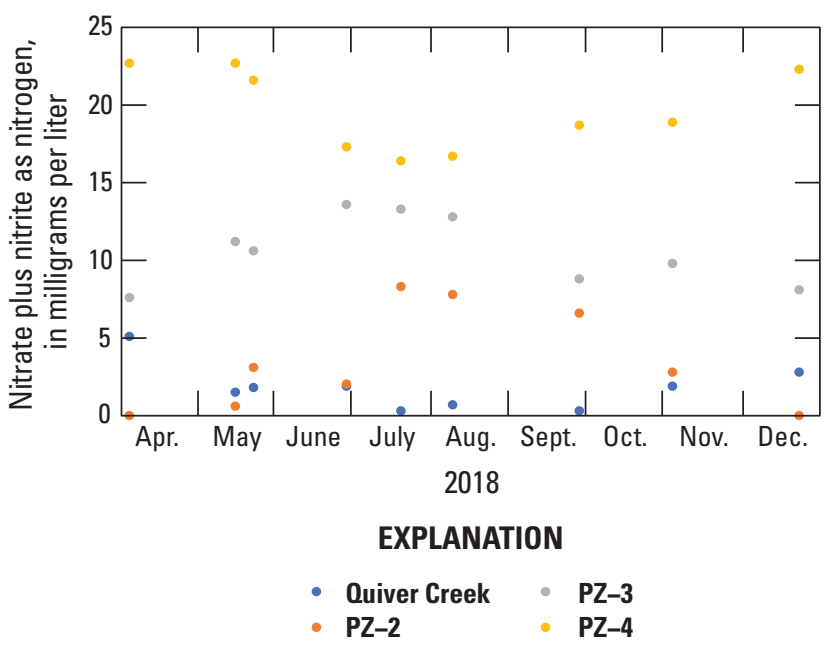

Figure 16. Nitrate concentrations in Quiver Creek and the shallow piezometers in the floodplain (PZ-2, PZ-3, and PZ-4) April 4, 2018, to December 19, 2018.

conditions are more reducing, with anoxic water favoring denitrification. During the installation of PZ-2B, visual observation between 8 and $12 \mathrm{ft}$ indicated the redoxcline defined at the tree nursery by Kelly (1997) was also existent in the floodplain but at a much shallower depth.
Instantaneous measurements of nitrate concentrations also varied temporally. Quiver Creek nitrate concentrations decreased going into summer and then were consistently low in late summer and into the fall, except in 2018 when there was above average rainfall and concentrations were higher in the fall and winter than in 2017. Concentrations at PZ-2 and PZ-3 were low in spring, increased through summer, and then began to decline as Quiver Creek concentrations were increasing. Concentrations at PZ-3B and PZ-4 were similar to those in Quiver Creek, starting with higher nitrate concentrations that decreased going into summer and then began increasing going into fall and winter. These concentrations would also indicate limited lateral discharge of the shallow groundwater system to Quiver Creek. Farther from the stream, such as the location of PZ -4 , nitrate is similar to what is observed in the summer at the continuous monitoring well (Havana well).

The slowly decreasing nitrate concentrations may result from the deeper irrigation water, when fertilizer is not added, being delivered at the surface and moving to the water table, slowly diluting the nitrate signal throughout the summer. If fertigation was occurring and nitrate was being delivered in solution, it would be expected to be more evenly broadcast than physical application, which would lead to a more subtle response in the data, and this is what tends to be observed in the middle of the summer at some locations. 


\section{Isotopic Characterization}

In 2017, three discrete isotope samples were collected at the Havana well and analyzed for stable isotopes of groundwater and nitrogen. These discrete samples were collected in 2017, before, during, and after intensive agricultural operations. Additionally, in 2018, the Quiver Creek floodplain was sampled for these isotopes. Samples were collected from PZ-3 in spring 2018, and from PZ-2, PZ-3, and PZ-4 on July 18, 2018. Stable isotopes of groundwater from the Havana well and the piezometers plot close to one another and overlap on the Global Meteoric Water Line, indicating the source of recharge is the same for the well and the piezometers (fig. 17; Craig, 1961). A more refined local or regional meteoric water line may be beneficial in better understanding how these samples plot, and if evaporation of irrigation water is playing a role in isotopic composition of the groundwater at different times of the year. Results for nitrogen isotope samples had low isotope ratios, which is indicative of little denitrification and of chemical fertilizer being the source of the elevated nitrate levels (table 5; Kendall and others, 2008). The nitrate isotopes collected in the well and the piezometers plot in the typical range for ammonium in fertilizer (fig. 18; Kendall and others, 2008). Although isotope samples in the floodplain indicate chemical fertilizer as the source of the nitrate, there were not enough samples to confirm this finding. Additionally, samples for analyses of chloride concentrations and major ions would be helpful in further understanding this system, especially regarding mixing. According to Dubrovsky and others (2010), as much as 100 percent denitrification has been documented in riparian zones; however, nitrate concentrations and associated isotopic values measured in the Quiver Creek floodplain may be the result of several mechanisms. The primary mechanism is believed to be the upwelling and mixing of deeper lowernitrate groundwater with the higher-nitrate shallow groundwater as evidenced by water levels measured in the piezometers and large differences in measured nitrate and dissolved oxygen concentrations between the deep and shallow piezometers. Anoxic conditions at depth would favor denitrification and deeper groundwater tends to be more reduced, potentially having electron donors that would favor the reduction of oxygen and nitrate in the shallow higher-nitrate groundwater (McCallum and others, 2008). Other mechanisms that may be involved are microbial denitrification and plant uptake.

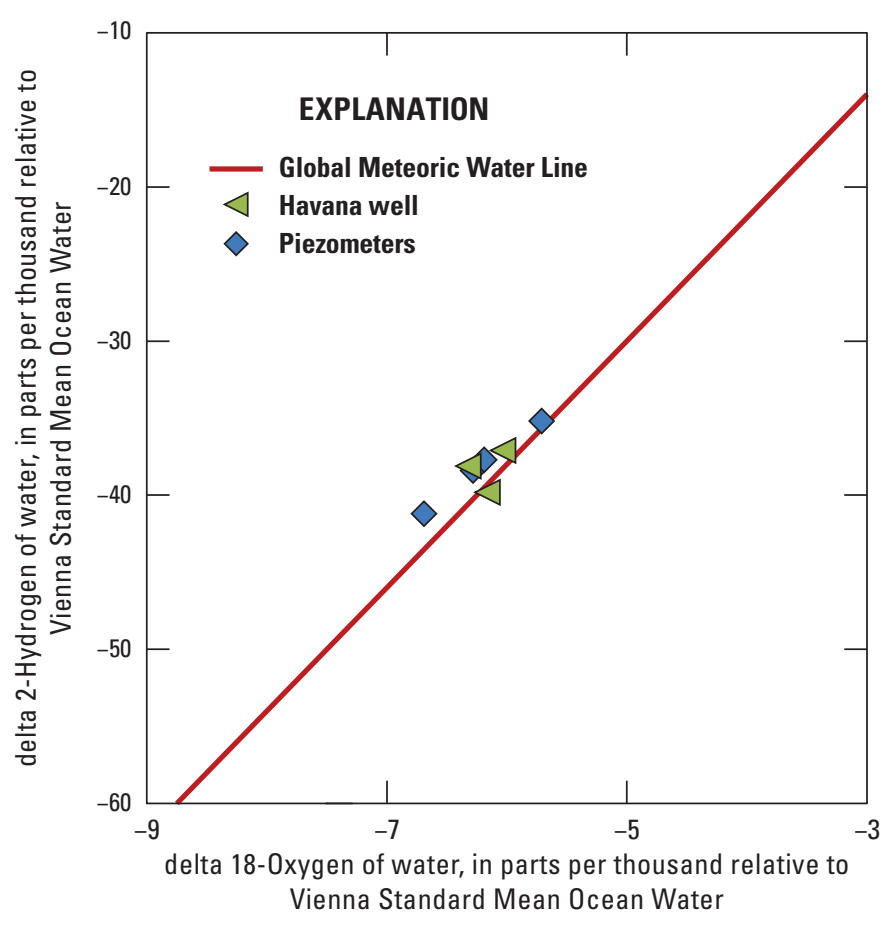

Figure 17. Stable isotopic composition of water from Havana well and Quiver Creek piezometers plotted on the Global Meteoric Water Line (Craig, 1961), Mason County, Illinois. 
Table 5. Summary of results of stable isotopes of water and nitrate isotopes in groundwater, Mason County, Illinois.

[M, month; D, day; YYYY, year; mg/L, milligram per liter; H, hydrogen; O, oxygen; N, nitrogen]

\begin{tabular}{|c|c|c|c|c|c|c|}
\hline Field identifier & $\begin{array}{c}\text { Date } \\
\text { (M/D/YYYY) }\end{array}$ & $\begin{array}{l}\text { Total nitrogen, } \\
\text { in } \mathrm{mg} / \mathrm{L}\end{array}$ & $\begin{array}{l}\text { Delta } \mathrm{H}-2 / \mathrm{H}-1 \text { water, } \\
\text { unfiltered per million }\end{array}$ & $\begin{array}{c}\text { Delta } 0-18 / 0-16 \text {, water, } \\
\text { unfiltered per million }\end{array}$ & $\begin{array}{c}\text { Delta } N-15 / N-14 \text {, nitrate } \\
\text { water, filtered per million }\end{array}$ & $\begin{array}{c}\text { Delta } 0-18 / 0-16 \text {, nitrate } \\
\text { water, filtered per million }\end{array}$ \\
\hline Havana Well & $4 / 11 / 2017$ & 20.4 & -39.8 & -6.16 & 1.90 & 3.56 \\
\hline Havana Well & $6 / 13 / 2017$ & 21.4 & -38.1 & -6.32 & 3.28 & 3.56 \\
\hline Havana Well & $10 / 3 / 2017$ & 19.4 & -37.1 & -6.03 & 3.36 & 4.22 \\
\hline PZ-3 & $4 / 4 / 2018$ & 9.12 & -35.2 & -5.71 & 4.62 & 4.80 \\
\hline PZ-2 & $7 / 18 / 2018$ & 8.49 & -41.2 & -6.69 & 3.34 & 3.27 \\
\hline PZ-3 & $7 / 18 / 2018$ & 13.26 & -38.4 & -6.28 & 5.22 & 5.88 \\
\hline $\mathrm{PZ}-4$ & $7 / 18 / 2018$ & 17.25 & -37.7 & -6.19 & 2.15 & 1.33 \\
\hline
\end{tabular}




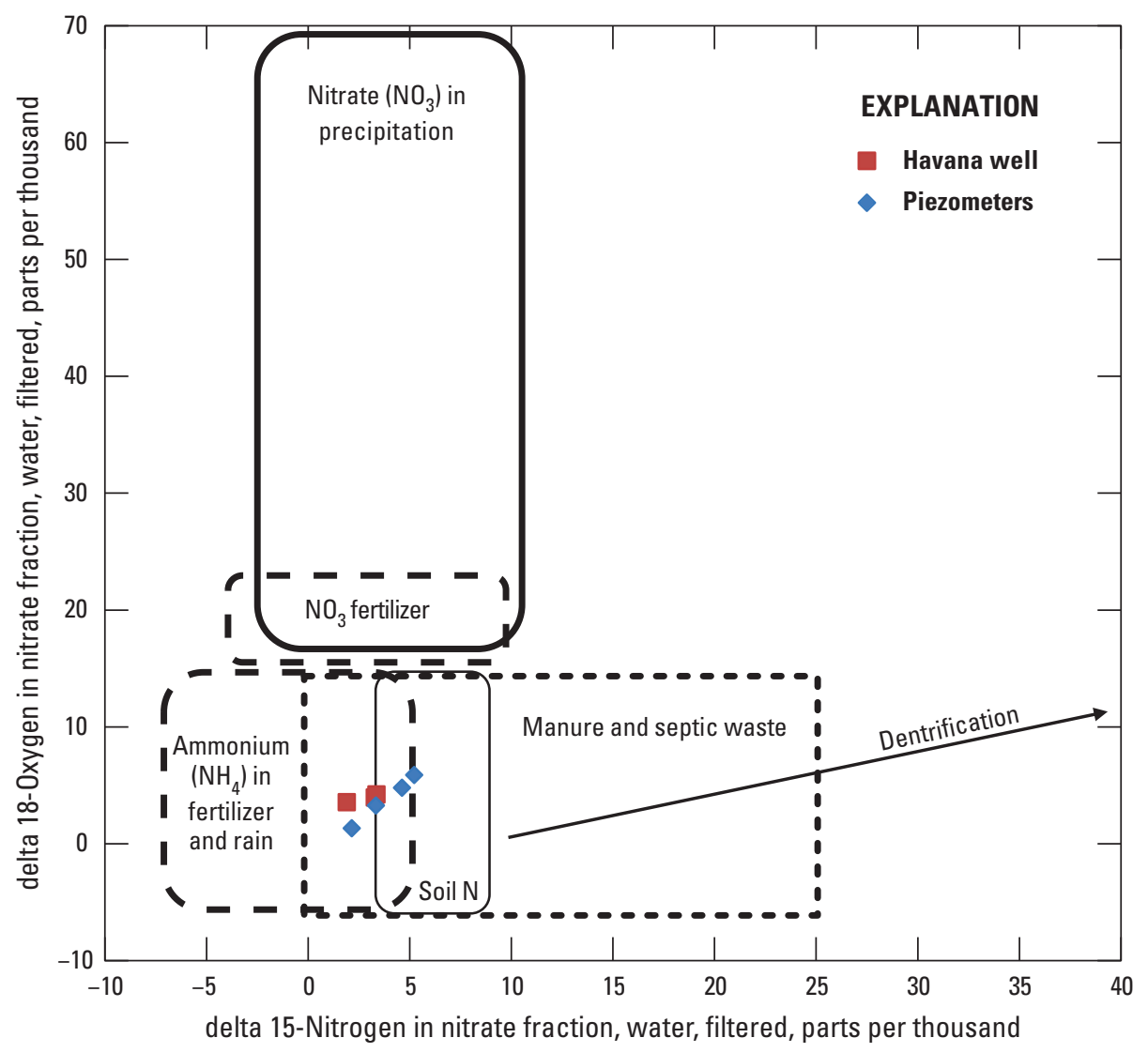

Figure 18. Nitrate isotopes for Havana well and Quiver Creek piezometers, Mason County, Illinois. Boxes represent typical ranges of delta 15-nitrogen and delta 18-oxygen isotope values of nitrate from various sources (Kendall and others, 2008).

\section{Summary and Conclusions}

The persistence of high nitrate concentrations in shallow groundwater has been well documented in the glacial aquifer of Mason County, Illinois. Studies have indicated that during low-flow periods, groundwater may be a substantial contributor to surface-water nitrogen loads, which can affect the Gulf of Mexico Hypoxic Zone. Understanding the fate and transport of nitrate in an area with persistently high nitrates will help better understand the potential contributions from groundwater to surface water.

From March 8, 2017, to March 31, 2019, continuous monitoring of groundwater level, continuous nitrate, dissolved oxygen, specific conductance, water temperature, and $\mathrm{pH}$ at U.S. Geological Survey station 401913089534501 indicated there were definite relations observed at smaller and larger temporal scales, most notably with nitrate and water levels, dissolved oxygen, and specific conductance. Observations during smaller time scales were difficult to assess without additional data that cover more environmental extremes. Larger scale fluctuations were related to recharge events and irrigation. During the irrigation season, water-quality data were often much more variable, and this variability most often occurred after water levels began to decline. This is presumed to be from the promotion of vertical flow during irrigation because the deeper water delivered from the irrigation systems is geochemically different than that of precipitation inputs and shallow groundwater.

Groundwater nitrate concentrations continuously measured in the Havana well during this time ranged from 14.7 to 23.2 milligrams per liter, whereas instantaneously measured nitrate concentrations in Quiver Creek ranged from 0.9 to 6.4 milligrams per liter. During the peak irrigation season, nitrate concentrations in the surface water are consistently low; it is likely that the Quiver Creek surface water is dominated by the deeper upwelling of low nitrate, anoxic groundwater from the Mahomet aquifer, with minimal input from the shallow oxic, high nitrate aquifer water. During those periods when the system is under recharge conditions and not under the stress of irrigation, higher nitrate concentrations are observed in the Quiver Creek surface water. Data indicate that during the growing season, irrigation usage may be minimizing lateral groundwater flow in the shallow system, effectively limiting its discharge to surface water. This effect may also be promoting denitrification and mixing within the floodplain, prior to discharge events to the stream. 
Temporally and spatially dense irrigation data would be beneficial to better understand the effects of the intensity and timing of irrigation, and how methods of fertilizer applications may affect water quality and potentially, groundwater flow. Additional isotope data in the Quiver Creek floodplain and surface water at different times of the year would be helpful to better understand this system in relation to mixing, denitrification, and source water. Streamflow measurement data and better temporal resolution in the surface water (specifically, water-level elevation, nitrate, dissolved oxygen, and specific conductance data) would be particularly helpful. These data would allow for confident calculations of nitrate loading throughout the year and help understand the fate and transport of nitrate in groundwater and how it may temporally affect nitrate loads in Quiver Creek.

\section{References Cited}

Bowman, J.A., Simmons, W.F., and Kimpel, B.C., 1991, Irrigation in Midwest-Lessons from Illinois: Journal of Irrigation and Drainage Engineering, v. 117, no. 5, accessed March 26, 2019, at https://doi.org/10.1061/(ASCE)07339437(1991)117:5(700).

Bridges, K., and Wilson, S., 2014, 2012 Center pivot irrigation in Illinois: ISWS Map Series 2014-01, 1 p., accessed February 27, 2020, at https://www.isws.illinois.edu/docs/ default-source/maps/2012-center-pivot-irrigation-masoncounty-illinois.pdf?sfvrsn $=5 \mathrm{~b} 30 \mathrm{~d} 2 \mathrm{c} 0 \_2$.

Chapelle, F.H., 1993, Ground-water microbiology and geochemistry: New York, NY, John Wiley \& Sons, Inc., 468 p.

Coplen, T.B., Qi, H., Révész, K., Casciotti, K., and Hannon, J.E., 2012, Determination of the $\delta 15 \mathrm{~N}$ and $\delta 18 \mathrm{O}$ of nitrate in water; RSIL lab code 2900, chap. 17 of Stable isotoperatio methods, sec. C of Révész, Kinga, and Coplen, T.B. eds., Methods of the Reston Stable Isotope Laboratory (slightly revised from version 1.0 released in 2007): U.S. Geological Survey Techniques and Methods, book 10, 35 p., accessed April 2020 at https://pubs.usgs.gov/tm/2006/ tm10c17/. [Supersedes version 1.0 released in 2007.]

Craig, H., 1961, Standard for reporting concentrations of deuterium and oxygen-18 in natural waters: Science, v. 133, no. 3467, p. 1833-1834. [Also available at https://doi.org/ 10.1126/science.133.3467.1833.]

Dubrovsky, N.M., Burow, K.R., Clark, G.M., Gronberg, J.M., Hamilton, P.A., Hitt, K.J., Mueller, D.K., Munn, M.D., Nolan, B.T., Puckett, L.J., Rupert, M.G., Short, T.M., Spahr, N.E., Sprague, L.A., and Wilber, W.G., 2010, The quality of our Nation's waters-Nutrients in the Nation's streams and groundwater, 1992-2004: U.S. Geological Survey Circular 1350, 174 p. [Also available at https://water.usgs.gov/nawqa/nutrients/pubs/circ1350.]
Fishman, M.J., ed., 1993, v. 93-125. Methods of analysis by the U.S. Geological Survey National Water Quality Laboratory-Determination of inorganic and organic constituents in water and fluvial sediments, U.S. Geological Survey Open-File Report, 217 p. [Also available at https://doi.org/10.3133/ofr93125.]

Gruhn, L.R., and Nalley, G.M., 2020, Continuous nitrate monitoring in groundwater and potential contribution to surface-water nitrogen loads in Mason County, Illinois: U.S. Geological Survey Fact Sheet 2019-3064, 4 p. [Also available at https://doi.org/10.3133/fs20193064.]

Hackley, K.C., Panno, S.V., and Anderson, T.F., 2010, Chemical and isotopic indicators of groundwater evolution in the basal sands of a buried bedrock valley in the midwestern United States - Implications for recharge, rock-water interactions, and mixing: Geological Society of America Bulletin, v. 122, p. 1047-1066, accessed October 14, 2020, at https://doi.org/10.1130/B26574.1.

Illinois Department of Agriculture, 2019, Illinois nutrient loss reduction strategy: accessed August 21, 2019, at https://www2.illinois.gov/sites/agr/Resources/NutrientLoss/ Pages/default.aspx.

Illinois Pollution Control Board, 2019a, Title 35-Procedural and environmental rules, section 620.410 groundwater quality standard for class 1 - Potable resource groundwater: accessed August 29, 2019, at https://pcb.illinois.gov/ documents/dsweb/Get/Document-33425/.

Illinois Pollution Control Board, 2019b, Title 35Procedural and environmental rules, section 611.301 revised MCLs for inorganic chemical contaminants: accessed March 22, 2020, at https://pcb.illinois.gov/SLR/ IPCBandIEPAEnvironmentalRegulationsTitle35.

Imperial Valley Water Authority, 2019, Imperial Valley Water Authority homepage: accessed on August 21, 2019, at http://imperialvalleywaterauthority.org/.

Kelly, W.R., 1997, Heterogeneities in ground-water geochemistry in a sand aquifer beneath an irrigated field: Journal of Hydrology (Amsterdam), v. 198, no. 1-4, p. 154-176. [Also available at https://doi.org/10.1016/S00221694(96)03316-1.]

Kelly, W.R., and Ray, C., 1999, Impact of irrigation on the dynamics of nitrate movement in a shallow sand aquifer: Champaign, Illinois State Water Survey, Research Report 128, 59 p.

Kendall, C., Elliott, E.M., and Wankel, S., 2008, Tracing anthropogenic inputs of nitrogen to ecosystems, chap. 12 of Michener, R., and Lajtha, K., 2008, Stable Isotopes in Ecology and Environmental Science (2d ed.): Blackwell Publishing Ltd., p. 375-449. 
Layne Hydro, 2012, Petition to designate the Mahomet Aquifer as a Sole Source Aquifer: City of Champaign, Town of Normal, City of Urbana, University of IllinoisChampaign/Urbana, village of Savoy, City of Develan, Village of Mahomet, Village of Mansfield, City of Gilman.

McCallum, J.E., Ryan, M.C., Mayer, B., and Rodvang, S.J., 2008, Missing-induced groundwater denitrification beneath a manured field in southern Alberta, Canada: Journal of Applied Geochemistry, v. 23, no. 8, p. 2146-2155, accessed April 2020 at https://doi.org/10.1016/ j.apgeochem.2008.03.018.

Murphy, J.C., Hirsch, R.M., and Sprague, L.A., 2013, Nitrate in the Mississippi River and its tributaries, 1980-2010-An update: U.S. Geological Survey Scientific Investigations Report 2013-5169, 31 p. [Also available at https://doi.org/ 10.3133/sir20135169.]

Patton, C.J., and Kryskalla, J.R., 2003, Methods of analysis by the U.S. Geological Survey National Water Quality Laboratory-Evaluation of alkaline persulfate digestion as an alternative to Kjeldahl digestion for determination of total and dissolved nitrogen and phosphorus in water: U.S. Geological Survey Water-Resources Investigations Report 2003-4174, 33 p. [Also available at https://doi.org/10.3133/ wri034174.]

Patton, C.J., and Kryskalla, J.R., 2011, Colorimetric determination of nitrate plus nitrite in water by enzymatic reduction, automated discrete analyzer methods: U.S. Geological Survey Techniques and Methods, book 5, chap. B8, 34 p. [Also available at https://doi.org/10.3133/tm5B8.]

Révész, K., and Coplen, T.B., 2008a, Determination of the $\delta(18 \mathrm{O} / 16 \mathrm{O})$ of water: RSIL lab code 489: U.S. Geological Survey Techniques and Methods, book 10, chap. C2, 28 p.

Révész, K., and Coplen, T.B., 2008b, Determination of the $\delta(2 \mathrm{H} / 1 \mathrm{H})$ of water: RSIL lab code 1574: U.S. Geological Survey Techniques and Methods, book 10, chap. C1, 27 p.

Roadcap, G.S., Hackley, K.C., and Hwang, H.H., 2002, Application of nitrogen and oxygen isotopes to identify sources of nitrate: accessed on April 22, 2020, at https://www.ideals.illinois.edu/bitstream/handle/2142/ 55259/roadcap2002.pdf.
Sanderson, E.W., and Buck, A.G., 1995, Reconnaissance study of the ground-water levels in the Havana lowlands area: Champaign, Illinois State Water Survey Contract Report $582,63 \mathrm{p}$.

U.S Department of Agriculture, 2012, National Agricultural Statistics Service Census of Agriculture, Mason County, Illinois: accessed August 2020 at https://www.nass.usda.gov/Publications/AgCensus/2012/ index.php.

U.S. Department of Agriculture, 2017, National Agricultural Statistics Service Census of Agriculture, Mason County, Illinois: accessed April 2020 at https://www.agcensus.usda.gov.

U.S. Environmental Protection Agency, 2019, National primary drinking water regulations: accessed June 9, 2019, at https://www.epa.gov/ground-water-and-drinking-water/ national-primary-drinking-water-regulations.

U.S. Environmental Protection Agency, 2020, Hypoxia 101What is hypoxia and what causes it?: U.S. Environmental Protection Agency web page, accessed on February 27, 2020, at https://www.epa.gov/ms-htf/hypoxia-101.

U.S. Geological Survey, variously dated, National field manual for the collection of water-quality data: U.S. Geological Survey Techniques of Water-Resources Investigations, book 9, chaps. A1-A10 [variously paged], accessed April 2020 at https://pubs.usgs.gov/twri/twri9a5/.

U.S. Geological Survey, 2020, USGS water data for the Nation: U.S. Geological Survey National Water Information System database, accessed September 17, 2020, at https://doi.org/10.5066/F7P55KJN.

Walker, W.H., Bergstrom, R.E., and Walton, W.C., 1965, Preliminary report on the ground-water resources of the Havana region in west-central Illinois: Illinois State Water Survey Cooperative Ground-Water Report 3, 61 p. 
For more information about this publication, contact: Director, USGS Central Midwest Water Science Center 405 North Goodwin

Urbana, IL 61801

217-328-8747

For additional information, visit: https://usgs.gov/centers/cm-water

Publishing support provided by the Rolla Publishing Service Center 
